\title{
An evaluation of the survival of experimental populations exposed to hypoxia in the Savannah River estuary*
}

\author{
Richard N. Winn**, David M. Knott \\ Marine Resources Research Institute, South Carolina Wildlife and Marine Resources Department, PO Box 12559, Charleston, \\ South Carolina 29412, USA
}

\begin{abstract}
The occurrence of hypoxia $\left(<2 \mathrm{mg} \mathrm{l}^{-1}\right)$ is being reported with increasing frequency in estuarine ecosystems; however the impacts of this environmental stress are often difficult to evaluate. Since changes induced by episodes of hypoxia or anoxia may be impossible to distinguish from the natural variability of biological communities, often it is only possible to infer effects based on measurements of low dissolved oxygen that coincide with events of catastrophic mortality. In the present study, alteration in the operational schedule of a tide gate in the Back River estuary (Savannah, Georgia, USA) enabled an examination of the responses of 3 species of estuarine organisms to hypoxia; survival was measured for caged amphipods Gammarus tigrinus and bivalves Mulinia lateralis and Mercenaria mercenaria deployed near the tide gate during phases of its operation (reduced ebb flow) and nonoperation (normal tidal flow). Water quality parameters showed that while the tide gate was operated during periods of seasonally elevated water temperature, bottom waters downstream of the gate became hypoxic. The interruption of normal ebb flow was clearly linked to the onset of increased stratification and resultant dissolved oxygen depletion. G. tigrinus was more sensitive to hypoxia than the bivalves, and laboratory tests suggested that mortality can result after as little as $3 \mathrm{~h}$ of exposure to oxygen saturation levels between 12 and $18 \%$. The possible ecological consequences of hypoxia in the Savannah River estuary are discussed.
\end{abstract}

\section{INTRODUCTION}

The occurrence of low levels of dissolved oxygen (hypoxia) in freshwater, estuarine and marine ecosystems has been extensively documented (e.g. Renaud 1985, Schroeder 1985). The increased frequency of oxygen deficiency in coastal waters of several regions of the USA, such as the Gulf of Mexico, Chesapeake Bay, the New York Bight, Virginia, New Jersey, and North Carolina, has prompted efforts to better understand oxygen depletion, including the mechanisms which control oxygen budgets, the impacts on the flora and

- Contribution no. 315 of the South Carolina Marine Resources Center

- Present address: Duke University School of the Environment Marine Laboratory, Pivers Island, Beaufort, North Carolina 28516, USA fauna, and the means to predict its spatial and temporal occurrence (e.g. Officer et al. 1984, Siegler et al. 1985). A variety of factors, such as freshwater runoff, river flow, water column stratification, biological processes, weather conditions, input of industrial and domestic wastes, and sediment disturbance from dredging may contribute to the formation of oxygen-depleted water.

The ecological impacts of hypoxia or anoxia in the environment can be extensive, but in many cases they are also difficult to evaluate. This is due, in part, to the difficulty of distinguishing changes induced by reduced dissolved oxygen (DO) from the inherent variability of natural biological communities, which respond continuously to the influence of a multitude of biological and environmental factors. Additionally, the lack of fundamental information regarding lethal and sub-lethal effects of low DO for many species thwarts a clear understanding of biological impacts. As a result, 
the effects of hypoxia on indigenous biota are often inferred from measurements of low oxygen levels which coincide with catastrophic mortality of various organisms, apparently as a result of oxygen depletion.

In the present study, the Savannah River estuary provided the setting for an examination of the responses of estuarine organisms to natural and humaninduced changes in water quality. This estuary, located on the southeastern Atlantic coast of the USA, is characterized by substantial temporal changes in salinity, flow velocities, and circulation patterns, all of which are influenced to some degree by channel configuration, freshwater discharge, and tidal volume. Water circulation in this region is further complicated by modifications, such as channel deepening and widening projects, which enhance functions of Savannah Harbor as a deep-draft port. The most distinctive of these modifications in the estuary is a tide gate sediment basin system designed to utilize the large tidal variation in the region to reduce sedimentation within Savannah Harbor. During operation of the tide gate, normal ebb tidal flow is effectively eliminated within a portion of the estuary.

The operation of the tide gate has been implicated as the cause of increased salinities in marshes of the Savannah National Wildlife Refuge (Pearlstine et al. 1989), and changes in flora and fauna have been attributed to the resultant salinity intrusion (J. Davis, U.S. Fish and Wildlife Service, pers. comm.). Concerns have also been expressed by various wildlife management agencies regarding the impact of changes in water quality on resident populations of the striped bass Morone saxatilis, the endangered shortnose sturgeon Acipenser brevirostrum, and other anadromous and estuarine organisms.

Our principal objective was to evaluate the responses of several species of invertebrate organisms to physical changes in the estuary that are associated with operation of the tide gate. This was accomplished by measuring the survival of caged experimental populations of 'target' organisms following periods of deployment near the tidegate during phases of its operation (reduced ebb flow) and non-operation (normal tidal flow). The use of caged organisms permitted control over a number of variables, including their restriction to specific geographic locations, position within the water column, and the duration of exposure. The experiments were designed to allow a comparison of survival at various locations in the vicinity of the tide gate, and also to provide control over certain hydrographic parameters that were influenced by manipulating the operation of the tide gate. Periodic measurements of salinity, dissolved oxygen and temperature were made during the experimental trials, along with extensive hourly monitoring over several months at the test sites. As an adjunct to the field trials, laboratory experiments were conducted on the tolerance of 2 target species to various levels of salinity and oxygen saturation.

\section{MATERIALS AND METHODS}

Study area. The field experiments were conducted within the Savannah River estuary, a geographic feature which defines the political boundary between South Carolina and Georgia, USA (Fig. 1). The Savannah River estuary branches into a series of interconnected distributaries, including the Front River as the main stem of the Savannah River, and the Back River. The lower region encompasses a partially mixed estuary with a 2-layered circulation pattern (Mathews et al. 1980). A tidal amplitude greater than $3 \mathrm{~m}$ that occurs in this part of the estuary is exceeded along the east coast of the USA only between Maine and Massachusetts.

The tide gate is located $18 \mathrm{~km}$ upstream from the mouth of the estuary in the Back River (Fig. 1a). The structure consists of 8 gates which are opened by hydrostatic head during the flood tide and closed at high slack water. The tidal prism in the Back River augments ebb flow via an upriver channel that was cut through to the Front River, resulting in higher ebb velocities in the Front River which move sediment past Savannah Harbor and eventually concentrate it within the sediment basin. The sediment basin $(3.2 \mathrm{~km}$ length, $180 \mathrm{~m}$ width, ca $12 \mathrm{~m}$ depth) is located at the lower end of the Back River estuary, approximately $900 \mathrm{~m}$ downstream of the tide gate. It is connected to the Front River shipping channel by a $488 \mathrm{~m}$ entrance channel (Fig. 1a). During inoperation the gates are raised, permitting normal ebb tidal flow.

To evaluate spatial patterns of hydrography and survival of test organisms (relative to proximity to the tide gate), we established an initial array of 6 stations at increasing distances from the tide gate in the Back River estuary. For the first trials in October 1988, 3 stations were located above (Stns AG1 to AG3) and 3 below (Stns BG1 to BG3) the tide gate (Fig. 1a). Upstream stations AG1, AG2 and AG3 were located approximately 250,1000 and $3200 \mathrm{~m}$ from the tide gate, respectively, in depths ranging from 1.3 to $5.5 \mathrm{~m}$. Stns $B G 1, B G 2$ and $B G 3$ were located at equivalent distances downstream from the tide gate. BG1 was situated just upstream of the sediment basin at a depth of 3.7 to $6.4 \mathrm{~m}$, while the 2 stations within the sediment basin (BG2 and BG3) were located at depths between $8.5 \mathrm{~m}$ and $12.3 \mathrm{~m}$, depending upon the tidal stage.

During trials conducted in summer 1989, two of the upstream stations (AG1 and AG3) were replaced by additional stations within the sediment basin, in order 
to concentrate our efforts in that vicinity. Stn ST1 was retained above the tide gate (equivalent to $A G 2$ ), and ST2 (equivalent to BG1) was situated on the sill directly below the tide gate. The remaining stations (ST3 to ST6) were near mid-channel within the sediment basin at roughly equal distances from one another (1000, 1900, 2900 and $3800 \mathrm{~m}$ below the tide gate; Fig. 1b). Bottom depths at these basin stations varied between 10.0 and $13.9 \mathrm{~m}$, depending upon the location and tidal stage.

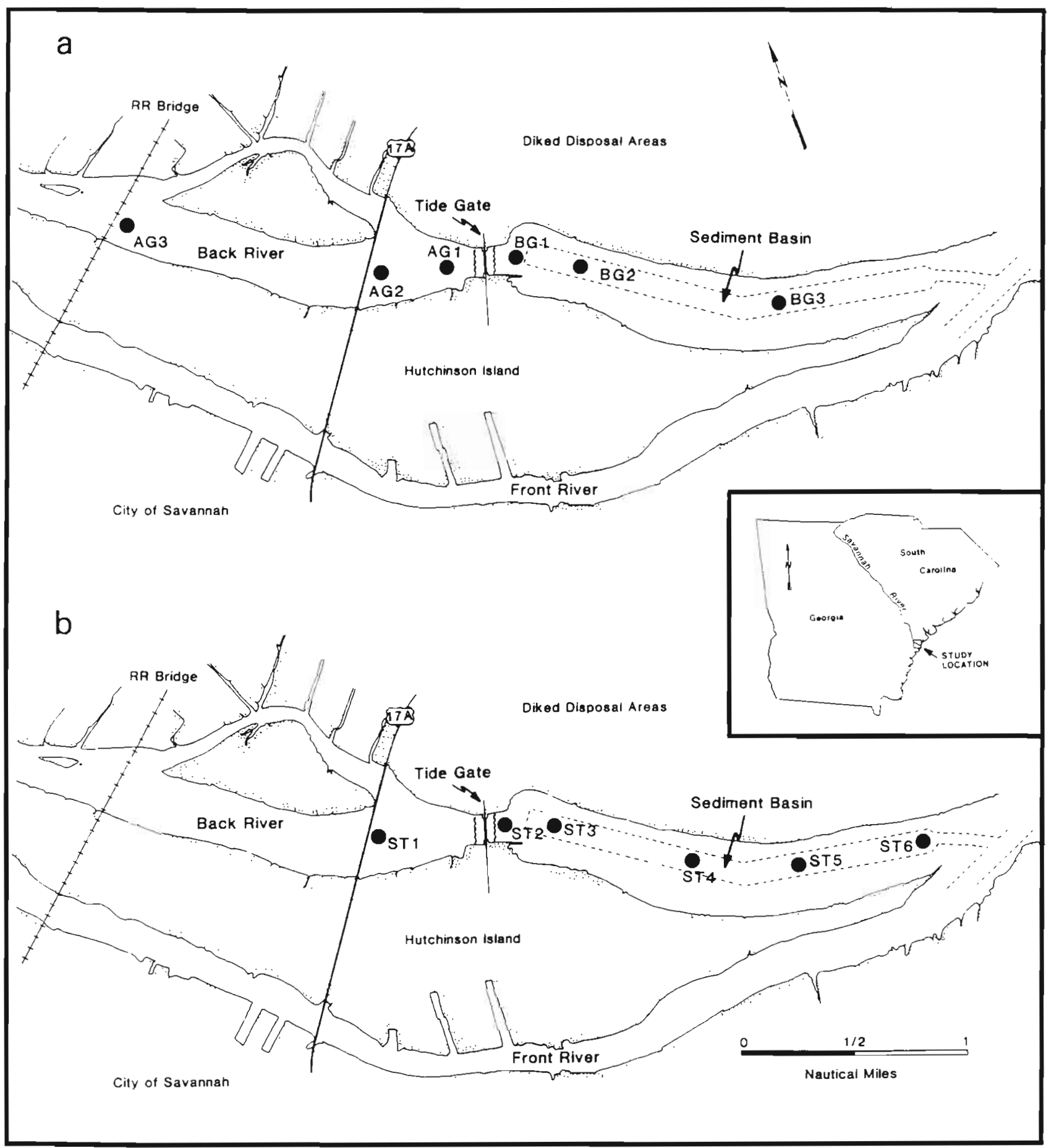

Fig. 1. Approximate locations of (a) autumn (1988) and (b) summer (1989) study stations in the lower Savannah River estuary of South Carolina and Georgia, USA. 
Field experiments. We selected 3 species of invertebrate organisms and evaluated their responses to changes in selected hydrographic parameters induced by the operation of the tide gate: the gammarid amphipod Gammarus tigrinus, the dwarf surf clam Mulinia lateralis, and the hard clam Mercenaria mercenaria. These species were determined to be representative of regional estuarine habitats and were chosen for their tolerance of natural ambient conditions, ease of handling, and local availability. Prior to use in field experiments, animals were held in aquaria and acclimated to 10 to $15 \%$ salinity for at least $48 \mathrm{~h}$ before field deployment.

Gammarus tigrinus, a common endemic gammarid that occurs in oligohaline and brackish portions of estuaries along the east coast of USA, is an omnivorous benthic species that feeds mainly on plant material (E. Bousfield pers. comm.). The adult specimens used in our in situ tests were collected from an extensive and persistent population inhabiting Elodea beds roughly $28 \mathrm{~km}$ from the mouth of the Cooper River estuary, near Charleston Harbor, South Carolina.

Mature individuals of Mulinia lateralis, a widely distributed and often cominant member of the estuarine benthos inhabiting fine sediments in coastal Georgia (Walker \& Tenore 1984) and South Carolina, were collected from dense populations $\left(>25000 \mathrm{~m}^{-2}\right)$ in Charleston Harbor. This small euryhaline mactrid clam (Williams 1984) was used during the first set of trials in the autumn of 1988. This clam, however, which was characterized by Shumway et al. (1983) as a strongly r-selected opportunistic species, experiences frequent major spatial and temporal fluctuations in abundance (Boesch et al. 1976, Santos \& Simon 1980, Walker \& Tenore 1984), and it was not available in sufficient quantities for use in the summer trials. Consequently, hard clams Mercenaria mercenaria were obtained from a 1 -yr-old population (10 to $30 \mathrm{~mm}$ shell length) cultured at a mariculture facility (South Carolina Wildlife and Marine Resources Department, SC, USA), replacing $M$. lateralis during the later experiments. This species is widely distributed throughout South Carolina and Georgia, with greatest densities and growth on sandy shelly substrata where salinities generally remain higher than about $12 \%$ (Eversole 1987).

Amphipods and clams were placed separately in groups of 10 into cylindrical PVC test chambers $(7.6 \mathrm{~cm}$ diameter $\times 12.5 \mathrm{~cm}$ length) fitted with $0.5 \mathrm{~mm}$ mesh screen over one end and a removable solid lid over the other. Four ventilation holes $(3.3 \mathrm{~cm}$ diameter) were drilled in the wall of the chamber and covered with screen $(0.5 \mathrm{~mm}$ for amphipods; $0.75 \mathrm{~mm}$ for clams) to retain organisms while enhancing water circulation within the chambers. Each experimental unit consisted of a buoyed anchor line with 2 test chambers (one with each of the 2 target species) suspended ca $1 \mathrm{~m}$ below the surface and 2 others ca $1 \mathrm{~m}$ above the bottom.

Autumn 1988 trials: On October 7, 1988, a pilot study was initiated at Stns BG1 (on the sill immediately downstream of the tide gate) and $\mathrm{BG} 2$ (within the sediment basin). The choice of these 2 sites downstream of the tide gate was based on results of earlier hydrographic measurements which indicated that while the tide gate operates during the warm seasons, a body of hypoxic bottom-water resides within the sediment basin. Since depressed levels of dissolved oxygen were expected to be among the most significant effects of the operation on the tide gate, these initial trials were designed to compare, in a limited spatial array, the survival of organisms placed within the basin with those exposed outside of it.

Following the completion of this pilot study, two $5 \mathrm{~d}$ trials were conducted at the full array of 6 stations (Fig. 1a), with 3 buoyed lines per station. One test was conducted during a period of tide gate non-operation (October 20 to 25), and the other when the tide gate was functioning (November 7 to 12). Upon retrieval of the cages, the number of living organisms in each chamber was recorded. For the final trials with the tide gate operating, the clams were left in place for an additional $5 \mathrm{~d}$ to evaluate survival following extended exposure.

Summer 1989 trials: During summer 1989, 2 consecutive 5 d trials (Trials 1 \& 2) were conducted with amphipods when the tide gate was not operating (July 14 to 24) and again during normal operation (August 4 to 14). Survival of Mercenaria mercenaria was also evaluated during the same periods, with observations recorded on the 5 th and 10 th days of exposure.

Additional cages were deployed during tide gate operation (August 4 to 14) to compare survival of target organisms held at several depths in the water column within the sediment basin. Separate cages containing Gammarus tigrinus and Mercenaria mercenaria were attached at 3 additional intermediate levels [ca $1 / 4,1 / 2$ and $3 / 4$ of the distance between the surface $(-1 \mathrm{~m})$ and bottom $(-13 \mathrm{~m})$ cages] on each of the 3 buoyed lines at ST4.

Hydrographic parameter monitoring. Salinity, dissolved oxygen, and temperature measurements were taken ca $1 \mathrm{~m}$ below the surface and ca $1 \mathrm{~m}$ above the bottom with a portable instrument (Hydrolab Mark V, Model SVR2-SU, Hydrolab, Inc., Austin, TX, USA) at all sites during deployment and retrieval of the test chambers for the October 1988 trials, and also for many of the July-August 1989 trials. In addition, vertical profile measurements were taken at mid-depth and at $1 \mathrm{~m}$ intervals from surface to bottom at several sites during the trials.

During spring and summer 1989 (May 12 to August 
22), intensive water quality monitoring was performed by the US Geological Survey (Bennett et al. 1990) at each of the 6 sites where summer field experiments were conducted (ST1 to ST6; Fig. 1b). Each monitor consisted of a battery powered unit which measured conductivity, temperature and dissolved oxygen by means of probes deployed at ca $1 \mathrm{~m}$ below the surface and ca $1 \mathrm{~m}$ above the bottom. Measurements were recorded on paper tape at $1 \mathrm{~h}$ intervals. The upstream monitor (ST1) was attached to the superstructure of a bridge, while the remaining monitors (ST2 to ST6) were housed on anchored floating platforms adjacent to the buoys used for the field experiments. Data were transferred from the paper recording tape to magnetic tape for computer manipulation and analyses.

Salinity and dissolved oxygen tolerance tests. The survival of Mercenaria mercenaria and Gammarus tigrinus at various levels of salinity was evaluated using static-renewal tests conducted in the laboratory. Individuals of each species were acclimated for $>7 \mathrm{~d}$ to either $32 \%$ (M. mercenaria) or $15 \%$ (G. tigrinus), after which 10 individuals were placed in glass aquaria $(2$ aquaria per salinity treatment for each species) containing the following salinities: $0,5,10,15,20,25$ and $30 \%$. Amphipod survival was recorded every $24 \mathrm{~h}$ over a $5 \mathrm{~d}$ period, while clams were evaluated for $10 \mathrm{~d}$. Salinity levels were monitored every $24 \mathrm{~h}$ (YSI Model 33 S-C-T meter, Yellow Springs Instrument Co., Yellow Springs, $O H, U S A)$, and every $48 \mathrm{~h}$ approximately $75 \%$ of the water in each $4 \mathrm{l}$ amphipod chamber and $20 \mathrm{l}$ clam chamber was replaced and dead individuals were removed. Dissolved oxygen was monitored daily to insure that levels did not fall below $80 \%$ of saturation, and water temperature was maintained at 20 to $22^{\circ} \mathrm{C}$.

The survival of Gammarus tigrinus at various levels of oxygen saturation was evaluated in 5 separate laboratory experiments. Each trial consisted of equilibrating brackish water ( 8 to $10 \%$ ) to a particular level of oxygen saturation $(6,12,18,24$ or $36 \%)$ in 5 separate 11 Erlenmeyer flasks. A mixture of pressurized nitrogen and oxygen gas (USP grade) was delivered to the flasks via a proportional flowmeter (Aalborg, Inc., Monsey, NY, USA) through airlines fitted with pipette tips. During each trial, 5 additional chambers were aerated at or near oxygen saturation ( 84 to $96 \%$ ) to serve as controls. All tests were conducted at temperatures between 20 and $22^{\circ} \mathrm{C}$. Following the introduction of 10 amphipods to each chamber, dissolved oxygen levels were monitored every 30 min throughout the $6 \mathrm{~h}$ trial with an oxygen meter (YSI Model 57) that was calibrated against the azide modification of the Winkler titration (APHA 1980). Adjustments to the nitrogen/ oxygen gas flow were made as necessary, to keep DO levels within $\pm 0.2 \mathrm{mg} \mathrm{l}^{-1}$ of the desired treatment level. Observations of mortality were made concur- rently with DO measurements and at the termination of the test.

Data analyses. Statistical comparisons of the survival of target organisms at various positions in the water column (surface or bottom), station locations, and phases of tide gate operation were made using a 3-way Model I analysis of variance (ANOVA) on arcsine-transformed percent survival data $(\theta=$ arcsine $\sqrt{\% \text { survival } \times 0.01})$. One-way ANOVA was performed on arcsine-transformed values for survival of organisms exposed during the in situ water-column trials and also on survival in the laboratory tests of tolerance to salinity and dissolved oxygen. When significance was indicated by ANOVA, the a posteriori Student-Newman-Keuls test (Sokal \& Rohlf 1981) was used to determine the significance of differences among treatment group means $(\alpha=0.05)$. In order to account for the influence of varying water temperature and salinity on dissolved oxygen concentrations and the responses of test organisms to different DO levels, DO concentrations were reported as percent oxygen saturation values, following conversion using the formula of Benson \& Krause (1984). In some cases, however, simultaneous measurements of the 3 variables were not obtained, and in those instances oxygen concentrations are reported in $\mathrm{mg} \mathrm{l}^{-1}$.

\section{RESULTS}

\section{Field experiments}

\section{Autumn 1988 trials}

During the preliminary 5 d trial, survival of Gammarus tigrinus was clearly related to the location and depth of exposure while the tide gate was operating (Fig. 2). The significant interaction of those factors $(p<0.001)$ indicated that they were not independent in their effect on survival (Table 1). Survival rates in surface cages at both locations and in bottom cages on the sill (Stn BG1) were comparable (65 to $85 \%$ ). However, none of the amphipods exposed to the bottom water in the sediment basin (BG2) survived for $5 \mathrm{~d}$. Similarly, the greatest mortality of Mulinia lateralis also occurred at the sediment basin site, although differences in clam survival were not significant (Table 1).

Following these preliminary trials, tests of amphipod and clam survival were conducted throughout the lower Back River estuary during periods when the tide gate was out of operation (October 20 to 25, 1988) and also while it was operating normally (November 7 to 12,1988 ). In contrast to the pilot study, location and depth of exposure did not significantly influence survival of either Gammarus tigrinus or Mulinia lateralis 


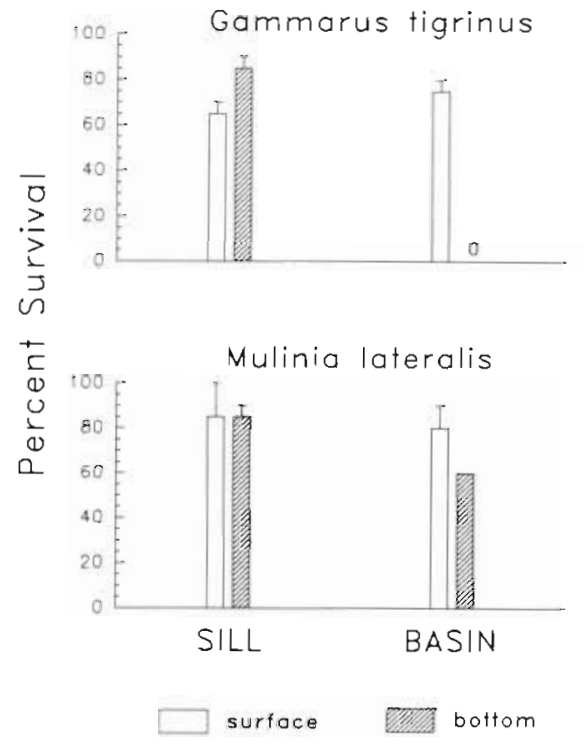

Fig. 2. Gammarus tigrinus and Mulinia lateralis. Survival $(\%)$ following $5 \mathrm{~d}$ field exposures at the surface $(-1 \mathrm{~m})$ and the bottom $(+1 \mathrm{~m})$ at the sill and sediment basin sites during tide gate operation. (Error bars denote 1 SE) during these subsequent trials (Fig. 3, Table 2). However, survival of $G$. tigrinus was significantly lower during tide gate operation than during the non-operational phase $(69 \%$ vs $88 \%, \mathrm{p}<0.001)$. Tide gate operation did not appear to increase mortality of $M$. lateralis during the $5 \mathrm{~d}$ exposure period, with mean survival of 95 to $96 \%$ among all sites during both phases of operation. However, after $10 \mathrm{~d}$ of exposure during tide gate operation, clam mortality increased (mean survival of $86 \%$ ), although a comparable $10 \mathrm{~d}$ test was not conducted during the earlier non-operational phase.

\section{Summer 1989 trials}

When field experiments were repeated the following summer, tests with Gaummarus tigrinus once again indicated the significance of location (with respect to the tide gate and sediment basin) and depth of exposure on survival (Fig. 4, Table 3). Amphipod survival was lower among individuals exposed near the bottom than among those near the surface (56 vs $84 \%$,

\section{Gammarus tigrinus}
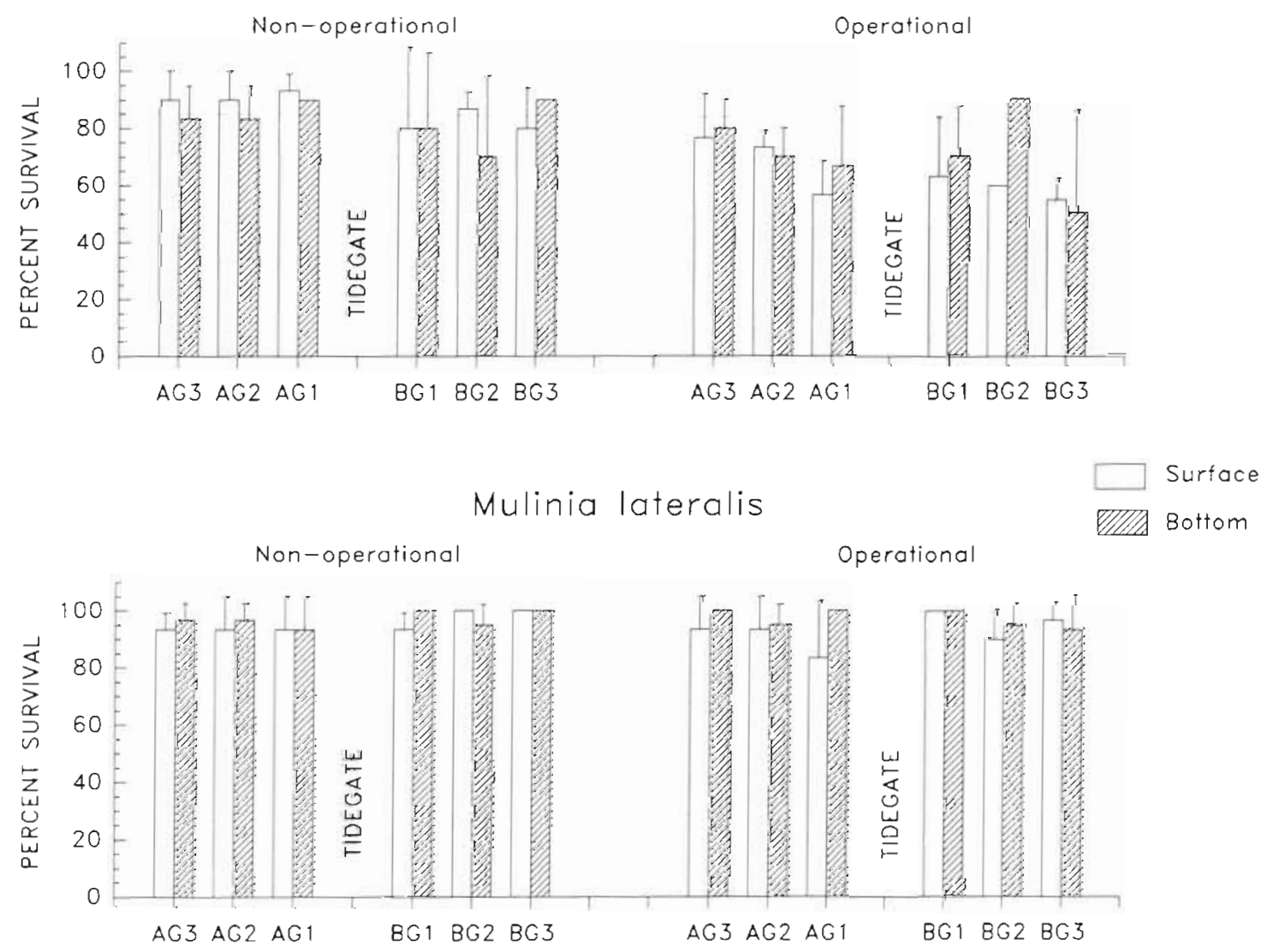

Fig. 3. Gammarus tigrinus and Mulinia lateralis. Survival $(\%)$ following $5 \mathrm{~d}$ field exposures at the surface $(-1 \mathrm{~m})$ and the bottom $(+1 \mathrm{~m})$ during non-operational and operational phases of the tide gate in autumn 1988. (The location of the tide gate relative to the study sites is indicatedi error bars denote 1 SE) 
Table 1. Results of 2-way ANOVA comparing the arcsine-transformed percent survival of Gammarus tigrinus and Mulinia lateralis in surface and bottom waters of the sill and basin locations during preliminary autumn trials. $\left({ }^{\prime} p<0.01 ; \cdots p<0.001\right.$; treatment means that are not connected by underlines as a result of a posteriori tests are significantly different from one another at the 0.05 level\}

\begin{tabular}{|c|c|c|c|c|}
\hline Dependent variable & Source of variation & df & $F$-value & Results of a posteriori test \\
\hline \multirow{5}{*}{ arcsine $\sqrt{\% \text { survival } \times 0.01}$} & Model $\left(I^{2}=0.98\right)$ & 3 & $83.96 \cdots$ & \multirow{9}{*}{$\begin{aligned} \underline{\text { sill }} & >\text { basin } \\
\underline{\text { surface }} & >\text { bottom }\end{aligned}$} \\
\hline & Factor A: Location & 1 & $82.11 \cdots$ & \\
\hline & (sill, basin) & & & \\
\hline & $\begin{array}{l}\text { Factor B: Depth } \\
\quad \text { (surface, bottom) }\end{array}$ & 1 & $62.55 \cdots$ & \\
\hline & $\begin{array}{l}\text { Interaction effects } \\
\quad(A \times B)\end{array}$ & 1 & $107.23 \cdots$ & \\
\hline Survival of & Model $\left(r^{2}=0.57\right)$ & 3 & $1.81 \mathrm{~ns}$ & \\
\hline \multirow{3}{*}{ arcsine $\sqrt{\% \text { survival } \times 0.01}$} & Factor A: Location & 1 & $2.80 \mathrm{~ns}$ & \\
\hline & $\begin{array}{l}\text { (sill, basin) } \\
\text { Factor B: Depth } \\
\text { (surface, bottom) }\end{array}$ & 1 & $1.24 \mathrm{~ns}$ & \\
\hline & $\begin{array}{l}\text { Interaction effects } \\
\qquad(\mathrm{A} \times \mathrm{B})\end{array}$ & 1 & $1.37 \mathrm{~ns}$ & \\
\hline
\end{tabular}

Table 2. Results of 3-way ANOVA comparing survival (arcsine-transformed percent) of Gammarus tigrinus and Mulinia lateralis in surface and bottom waters at the 6 study sites during operational and non-operational phases of the tide gate. $(\cdots p<0.001 ;$ treatment means that are not connected by underlines as a result of a posteriori tests are significantly different from one another at the 0.05 level)

\begin{tabular}{|c|c|c|c|c|}
\hline Dependent variable & Source of variation & $\mathrm{df}$ & $F$-value & $\begin{array}{c}\text { Results of } \\
\text { a posteriori test }\end{array}$ \\
\hline \multirow{2}{*}{$\begin{array}{c}\text { Survival of } \\
\text { Gammarus tigrinus }\end{array}$} & Model $\left(r^{2}=0.45\right)$ & 23 & $1.37 \mathrm{~ns}$ & \\
\hline & Factor A: Site & 5 & $1.07 \mathrm{~ns}$ & \\
\hline \multirow{8}{*}{ arcsine $\sqrt{\%}$ survival $\times 0.01$} & (AG3, AG2, AG1, BG1, BG2, BG3) & & & \\
\hline & $\begin{array}{l}\text { Factor B: Depth } \\
\quad \text { (surface, bottom) }\end{array}$ & 1 & $0.27 \mathrm{~ns}$ & \\
\hline & $\begin{array}{l}\text { Factor C: Operation phase } \\
\quad(\text { op, nonop) }\end{array}$ & 1 & $16.05 \cdots$ & non-op $>\underline{O P}$ \\
\hline & Interaction effects & & & \\
\hline & $(A \times B)$ & 5 & $0.17 \mathrm{~ns}$ & \\
\hline & $(A \times C)$ & 5 & $0.90 \mathrm{~ns}$ & \\
\hline & $(B \times C)$ & 1 & $2.00 \mathrm{~ns}$ & \\
\hline & $(A \times B \times C)$ & 5 & $0.47 \mathrm{~ns}$ & \\
\hline \multirow{3}{*}{$\begin{array}{c}\text { Survival of } \\
\text { Mulinia lateralis }\end{array}$} & Model $\left(\mathrm{r}^{2}=0.35\right)$ & 23 & $1.05 \mathrm{~ns}$ & \\
\hline & Factor A: Site & 5 & $0.68 \mathrm{~ns}$ & \\
\hline & (AG3, AG2, AG1, BG1, BG2, BG3) & & & \\
\hline \multirow{7}{*}{ arcsine $\sqrt{\%}$ survival $\times 0.01$} & $\begin{array}{l}\text { Factor B: Depth } \\
\quad \text { (surface, bottom) }\end{array}$ & 1 & $0.15 \mathrm{~ns}$ & \\
\hline & $\begin{array}{l}\text { Factor C: Operation phase } \\
\text { (op, nonop) }\end{array}$ & 1 & $0.64 \mathrm{~ns}$ & \\
\hline & Interaction effects & & & \\
\hline & $(A \times B)$ & 5 & $1.86 \mathrm{~ns}$ & \\
\hline & $(A \times C)$ & 5 & $1.43 \mathrm{~ns}$ & \\
\hline & $(\mathrm{B} \times \mathrm{C})$ & 1 & $0.00 \mathrm{~ns}$ & \\
\hline & $(A \times B \times C)$ & 5 & $0.70 \mathrm{~ns}$ & \\
\hline
\end{tabular}




\section{Tide Gate Non-operational}
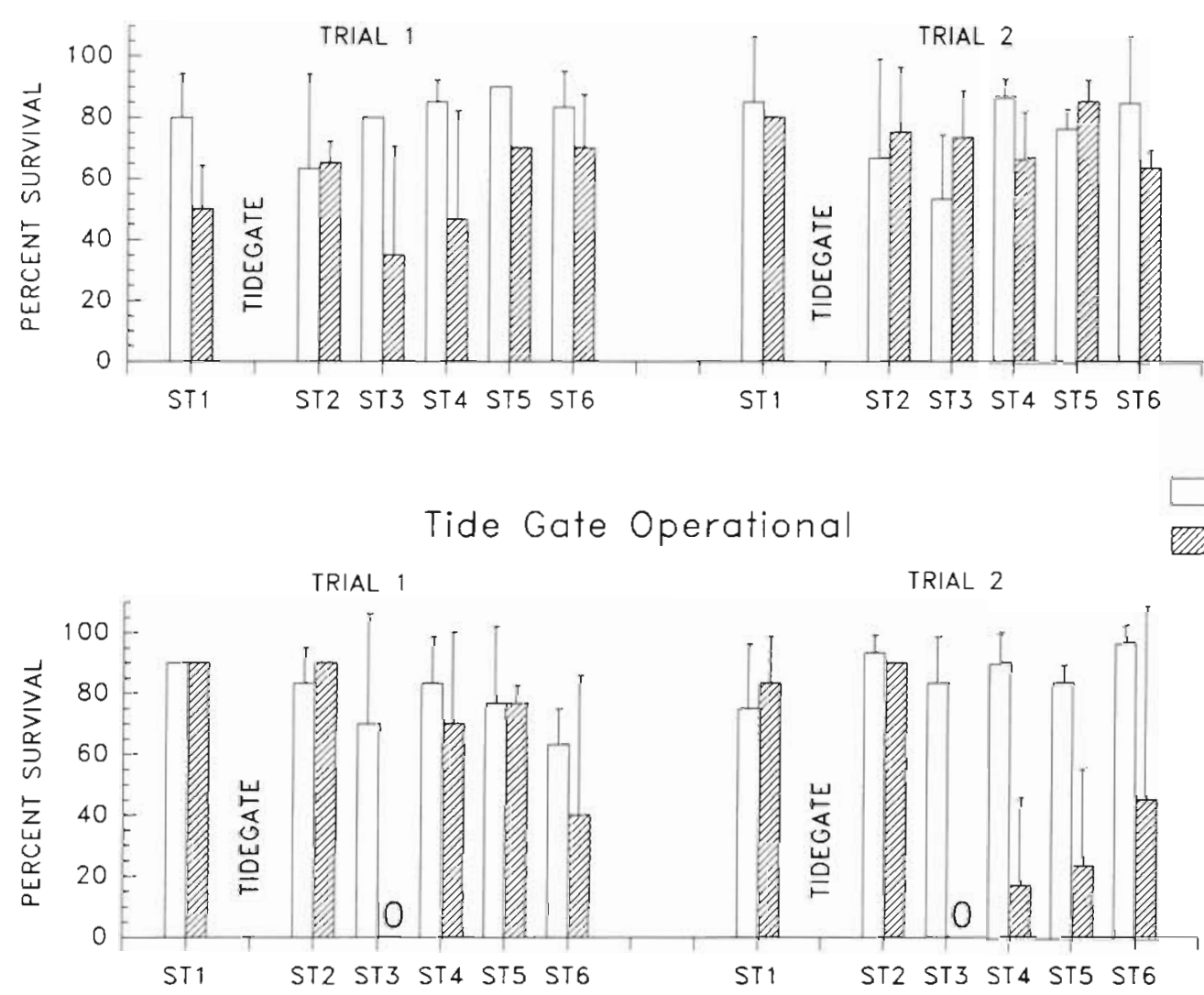

Fig. 4. Gammarus tigrinus. Survival $(\%)$ following $5 \mathrm{~d}$ field exposures at the surface $(-1 \mathrm{~m})$ and the bottom $(+1 \mathrm{~m})$ during nonoperational and operational phases of the tide gate in summer 1989. (The location of the tide gate relative to the study sites is indicated; error bars denote $1 \mathrm{SE}$ )

p $<0.001$ ), particularly at Stn ST3, located closest to the tide gate in the sediment basin. At that station, $100 \%$ mortality occurred during both operational trials (Fig. 4). Mean survival (without regard to depth of exposure) was highest at stations upriver of the sediment basin $(81 \%$ and $84 \%)$ and lowest at ST3 (47\%). Although the phase of tide gate operation was not itself significant as a main effect, its significant interaction with all other main effects indicated that they were not independent of one another (Table 3). Survival of amphipods in bottom cages was clearly reduced during tide gate operation, not only at ST3, but during Trial 2 at sediment basin Stns ST4, ST5, and ST6 as well (Fig. 4). The difference in survival between surface and bottom exposure at any particular location was also most pronounced within the sediment basin during tide gate operation (Trial 2), with mean surface and bottom survival rates of 92 and $16 \%$, respectively.

Results of tests with Mercenaria mercenaria clearly indicated that survival of clams was influenced largely by factors other than those which affected amphipod survival. While the tide gate was out of operation in July, very little mortality was observed within the first $5 \mathrm{~d}$ of exposure. However, by the end of the 10th day, most of the clams at the surface had died (Fig. 5). During this trial, surface salinities were extremely low at all stations, particularly during the last $5 \mathrm{~d}$ of the trial, while salinities remained considerably higher at the bottom within the sediment basin (see section on hydrography, below).

In contrast to amphipod mortality, which occurred primarily near the bottom within the sediment basin, mortality of clams was generally equivalent among all stations, including those above the tide gate (ST1) and on the sill (ST2). Analysis of variance confirmed that station location had no significant influence on clam survival, while depth and operational phase were both significant as main effects (Table 3). The interaction between depth and operation was also significant, with survival being greater at the bottom than at the surface $(p<0.001)$ during the period when the tide gate was not operating. During the operational phase in August, 
Table 3. Results of nested 3-way ANOVA comparing survival (arcsine-transformed percent) of Gammarus tigrinus and Mercenaria mercenaria in surface and bottom waters at the 6 study sites during operational and non-operational phases of the tide gate. $\left({ }^{\circ} p<0.05, \cdots p<0.01, \cdots p<0.001\right.$; treatment means that are not connected by underlines as a result of a posteriori tests are significantly different from one another at the 0.05 level)

\begin{tabular}{|c|c|c|c|c|}
\hline Dependent variable & Source of variation & $\mathrm{df}$ & F-value & $\begin{array}{c}\text { Results of } \\
\text { a posteriori test }\end{array}$ \\
\hline \multirow[t]{2}{*}{$\begin{array}{c}\text { Survival of } \\
\text { Gammarus tigrinus }\end{array}$} & Model $\left(r^{2}=0.52\right)$ & 25 & $4.46 \cdots$ & \\
\hline & Factor A: Site & 5 & $4.33 \cdots$ & ST1 ST2 ST5 ST6 ST $4>$ ST3 \\
\hline \multirow[t]{7}{*}{ arcsine $\sqrt{\% \text { survival } \times 0.01}$} & $\begin{array}{l}\text { (ST1, ST2, ST3, ST4, ST5, ST6) } \\
\text { Factor B: Depth } \\
\text { (surface, bottom) }\end{array}$ & 1 & $34.60 \cdots$ & surface $>$ bottom \\
\hline & $\begin{array}{l}\text { Factor C: Operation phase } \\
\quad(o p, \text { nonop) }\end{array}$ & 1 & $0.77 \mathrm{~ns}$ & \\
\hline & Trial within Factor $\mathrm{C}$ & 2 & $1.03 \mathrm{~ns}$ & \\
\hline & $(\mathrm{A} \times \mathrm{B})$ & 5 & $3.36 \cdots$ & \\
\hline & $(A \times C)$ & 5 & $2.59^{\cdot}$ & \\
\hline & $(\mathrm{B} \times \mathrm{C})$ & 1 & $8.10^{\cdots}$ & \\
\hline & $(A \times B \times C)$ & 5 & $2.92^{\bullet}$ & \\
\hline \multirow{2}{*}{$\begin{array}{l}\text { Survival of } \\
\text { Mercenaria mercenaria }\end{array}$} & Model $\left(r^{2}=0.67\right)$ & 25 & $8.32 \cdots$ & \\
\hline & Factor A: Site & 5 & $1.04 \mathrm{~ns}$ & \\
\hline \multirow[t]{8}{*}{ arcsine $\sqrt{\% \text { survival } \times 0.01}$} & $\begin{array}{l}\text { (ST1, ST2, ST3, ST4, ST5, ST6) } \\
\text { Factor B: Depth } \\
\text { (surface, bottom) }\end{array}$ & 1 & $40.89 \cdots$ & $\underline{\text { bottom }}>\underline{\text { surface }}$ \\
\hline & $\begin{array}{l}\text { Factor C: Operation phase } \\
\text { (op, nonop) }\end{array}$ & 1 & $41.79 \cdots$ & op $>$ nonop \\
\hline & Trial within Factor $\mathrm{C}$ & 2 & $44.85 \cdots$ & \\
\hline & Interaction effects & & & \\
\hline & $(\mathrm{A} \times \mathrm{B})$ & 5 & $0.77 \mathrm{~ns}$ & \\
\hline & $(A \times C)$ & 5 & $0.53 \mathrm{~ns}$ & \\
\hline & $(B \times C)$ & 1 & $23.10^{\cdots}$ & \\
\hline & $(A \times B \times C)$ & 5 & $0.17 \mathrm{~ns}$ & \\
\hline
\end{tabular}

10 d survival of $M$. mercenaria remained greater than $86 \%$ at all sites (Fig. 5).

The survival of amphipods exposed at various depths throughout the water column at ST4 was relatively high $(70$ to $83 \%)$ during the week following re-activation of the tide gate, with the exception of the 4 th position (ca $10 \mathrm{~m}$ depth). At that depth, reduced survival $(37 \%)$ coincided with a DO minimum $(18.5 \%$ saturation) after $5 \mathrm{~d}$ of exposure (Trial $1_{i}$ Fig. 6). The differences in survival at various depths during this trial were not significant ( $p>0.05$, ANOVA). By the following week (Trial 2), however, amphipod survival was dramatically reduced at all sub-surface depths. Total mortality occurred at all intermediate depths, with only a few survivors remaining in one of the bottom chambers. During the second trial, survival of amphipods remained high near the surface, where DO levels greater than $45 \%$ saturation were observed. Below the surface, DO diminished considerably, and by the end of the $5 \mathrm{~d}$ trial bottom waters at this site were nearly anoxic $(3.4 \%)$. In contrast to Gammarus tig- rinus, Mercenaria mercenaria showed little negative response to the depth gradient of exposure. Survival remained above $93 \%$ at all depths throughout the $10 \mathrm{~d}$ operational trial (Fig. 6), with survival rates similar to those observed in the surface and bottom chambers at the other 5 stations during the same trial.

\section{Hydrographic parameter monitoring}

Portable instruments

Oxygen saturation values recorded at the 6 stations during the autumn trials did not differ markedly from one another ( 65 to $82 \%$ ) (Fig. 7 a). Bottom values, while expectedly lower than those at the surface, were also quite similar to one another while the tide gate was out of operation ( 63 to $68 \%$ ). During operation of the tide gate, however, Stns BG2 and BG3 had markedly lower bottom DO values than the others (16 to $56 \%$ ).

A comparison of oxygen saturation at BG1 (on the 

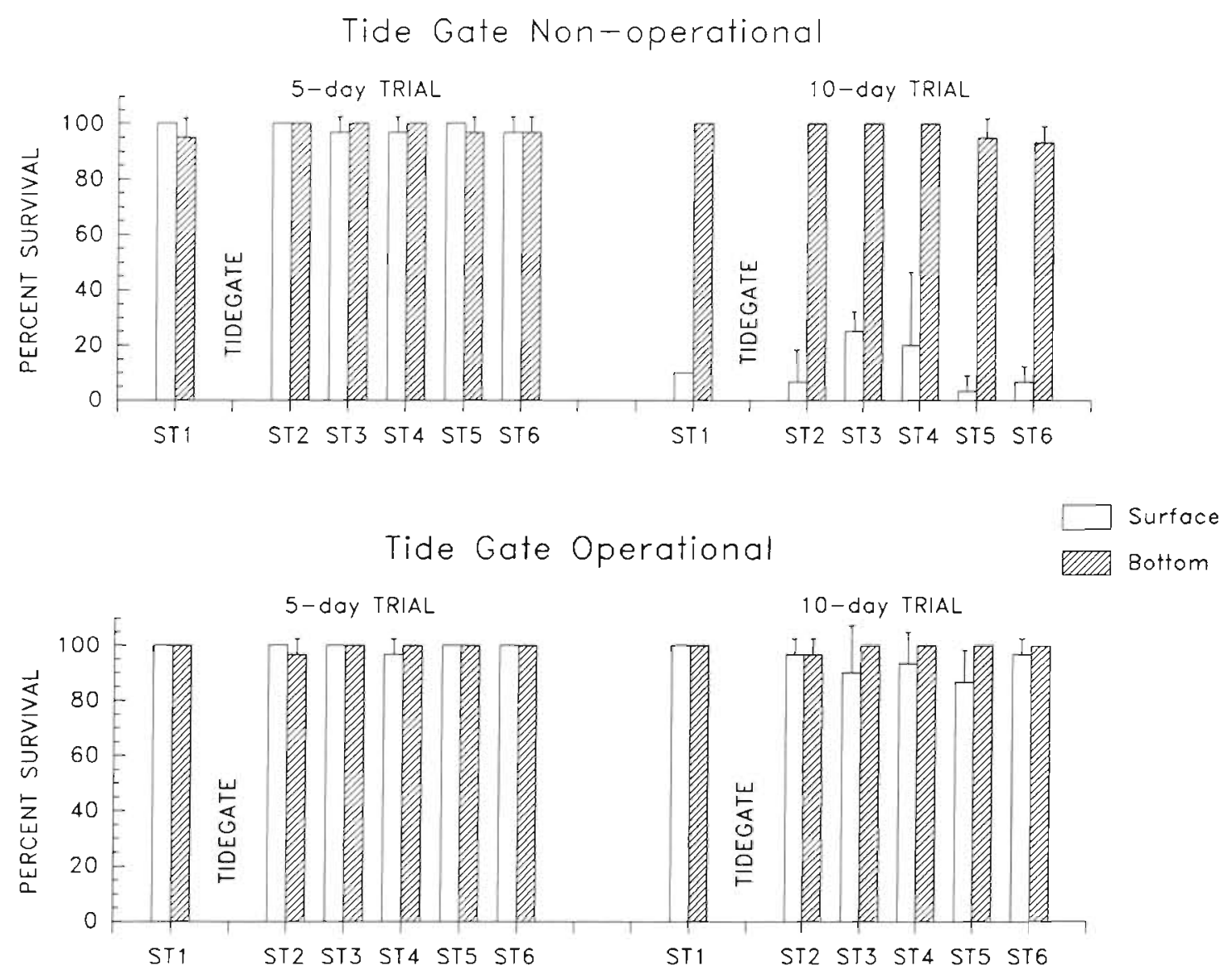

Fig. 5. Mercenaria mercenaria. Survival (\%) following 5 and $10 \mathrm{~d}$ field exposures at the surface $(-1 \mathrm{~m})$ and the bottom $(+1 \mathrm{~m})$ during non-operational and operational phases of the tide gate in summer 1989. (The location of the tide gate relative to the study sites is indicated; error bars denote $1 \mathrm{SE}$ )

sill) and BG1 (within the basin), where readings were available for 3 alternating phases of operation, revealed a similar pattern of depressed bottom DO within the basin which coincided with the operation of the tide gate (Fig. 8). Bottom saturation values within the basin were 40 to 68 percentage points lower than at the surface during tide gate operation. However, when the tide gate was not operating, bottom values were within $18 \%$ of the surface values, particularly in October, when the difference was less than $4 \%$. Upstream of the sediment basin, at BG1, bottom DO values were no more than 16 percentage points lower than surface readings throughout the same period (Fig. 8).

Vertical salirity and DO profiles made during tide gate operation on October 12, 1988 were quite similar at BG1 and BG2, down to the $7 \mathrm{~m}$ sill depth (Fig. 9). Within the sediment basin at BG2, the salinity increased substantially below that depth, while DO levels declined sharply between 9 and $10 \mathrm{~m}$ (from 3.4 to $0.2 \mathrm{mg} \mathrm{l}^{-1}$ )
During the summer trials in July and August 1989 surface oxygen saturation values were relatively similar (55 to $67 \%$ ) among all stations during non-operation of the tide gate (Fig. 7b). Although it was comparable among stations, saturation of surface waters was somewhat lower on August 4 during tide gate operation than at other times. Bottom DO measurements showed a pattern similar to that seen in the autumn, with lower values generally recorded within the sediment basin (ST3 to ST6) than outside of it during non-operation (Fig. 7b). Within $4 \mathrm{~d}$ of tide gate re-activation bottom DO values declined, with the sharpest reductions occurring within the basin. Following 2 wk of operation, bottom DO at the 2 upstream stations, ST1 and ST2, remained comparable to values during non-operation (55 and 50\% of saturation, respectively), while DO values at all basin sites declined to near anoxic levels $(<8 \%)$. Among the basin sites, DO values generally increased slightly with increasing distance from the tide gate. 

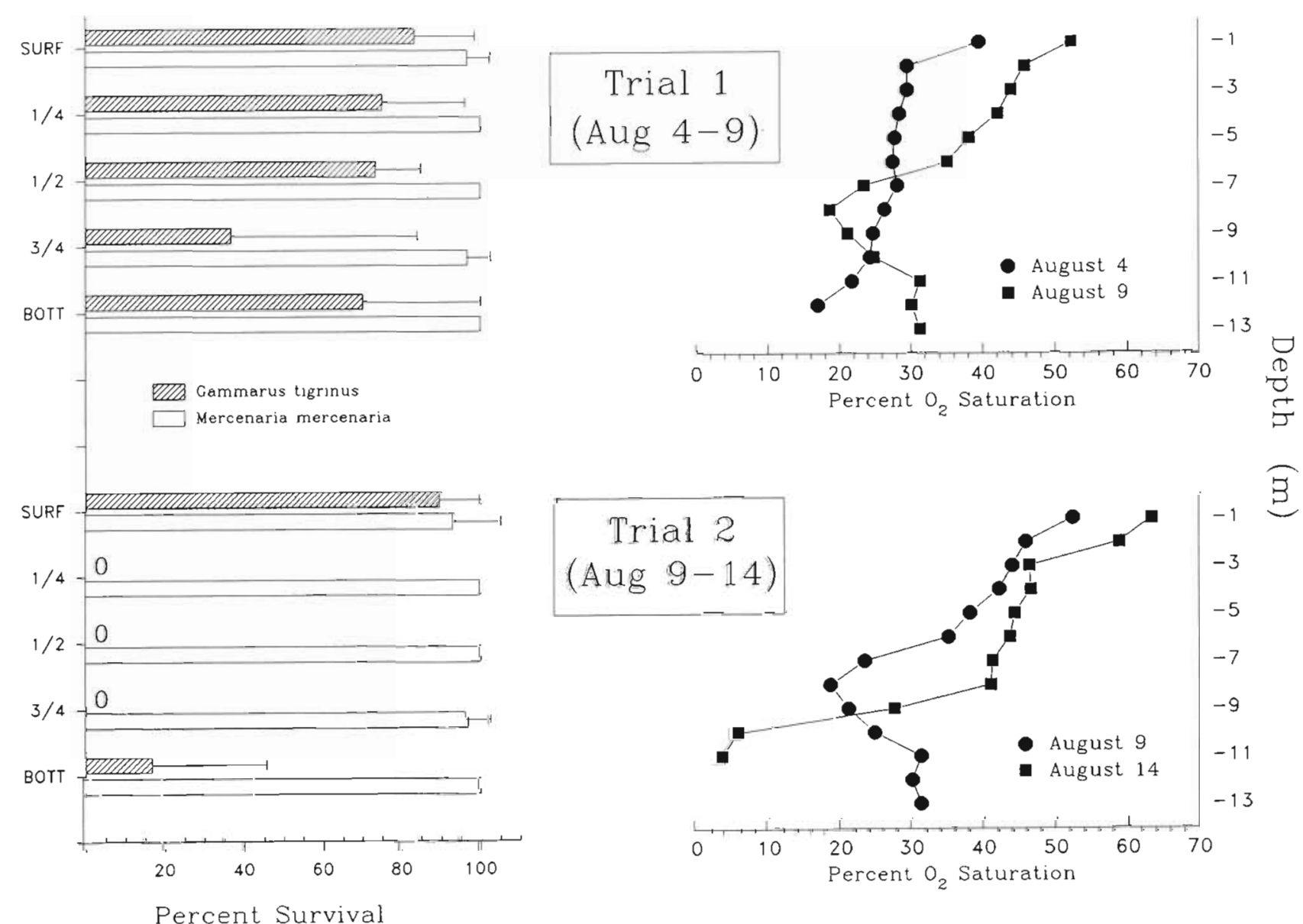

Fig. 6. Gammarus tigrinus and Mercenaria mercenaria. Survival (\%) following exposure in two 5 d experiments along a depth gradient throughout the water column at a site in the sediment basin (ST4). Also shown are temporal changes in the vertical profiles of oxygen saturation (\%) that were observed during the experiments. (Error bars denote $1 \mathrm{SE}$ )

Depth profiles of dissolved oxygen at ST4 on August 4, 9, and 14, 1989 illustrate the development of increasing stratification with time, following reactivation of the tide gate on August 1 (Fig. 6). On August 4 (Trial 1), oxygen saturation gradually declined from $39 \%$ at $-1 \mathrm{~m}$ to a minimum of $17 \%$ approximately $1 \mathrm{~m}$ above the bottom. Five days later a DO minimum within the water column was observed (18\% of saturation at $8 \mathrm{~m}$ depth), with slightly higher DO levels observed at the bottom. On August 14 a severe reduction in DO was observed between 8 and $10 \mathrm{~m}$, and near anoxic levels $(3.4 \%$ ) were recorded just above the bottom, similar to observations in the basin during the previous autumn trials. By the end of Trial 2, considerable stratification of dissolved oxygen had developed, with the bottom saturation value being 60 percentage points lower than the surface.

\section{Continuous recording monitors}

The daily mean values of surface and bottom DO and conductivity, calculated for the period of the field experiments (July 14 to 24 and August 4 to 14, 1989), are presented in the following analysis. Missing data points resulted when certain values indicated equipment failure; thus, gaps appear in the data for certain parameters. The entire data set (April to August 1989) of daily values of conductivity and $D O$, as well as water temperature, are presented for each station by Bennett et al. (1990).

Conductivity generally declined during the July trials and increased during the August trials at most sites (Fig. 10). Surface conductivity dropped considerably over the course of the non-operational trials in July, declining below $8800 \mu \mathrm{S} \mathrm{cm}^{-1}$ (ca $4.6 \%$ salinity) at all stations by the end of that $2 \mathrm{wk}$ test period. Vertical stratification 


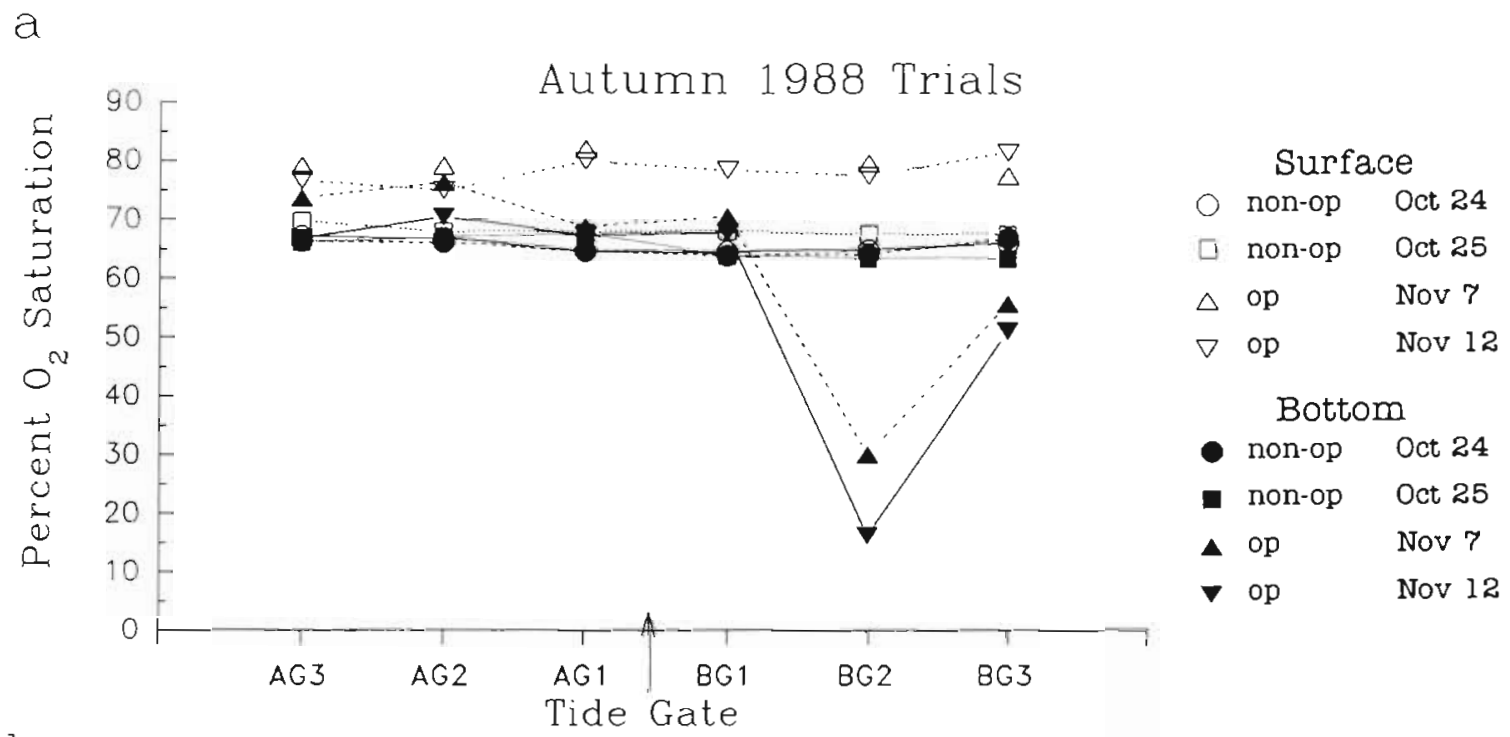

$\mathrm{b}$

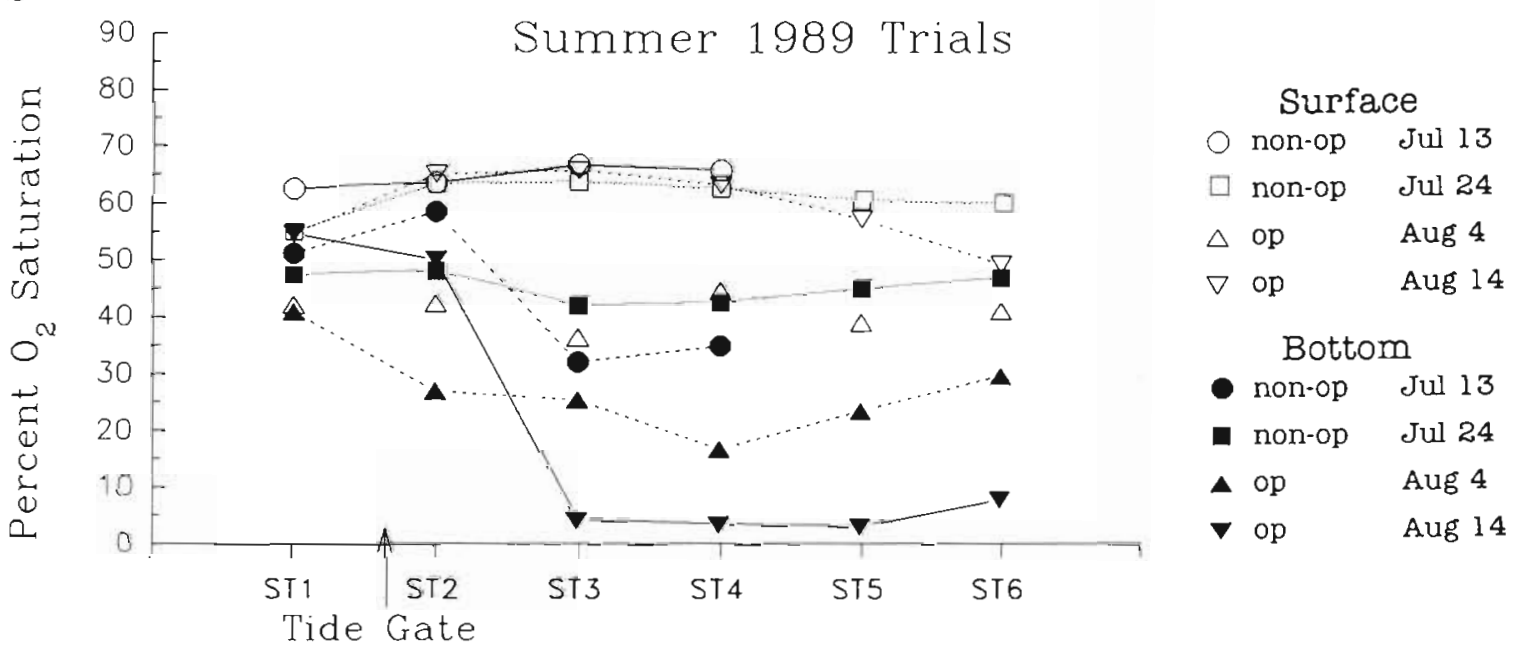

Fig. 7. Surface $(-1 \mathrm{~m})$ and bottom $(+1 \mathrm{~m})$ oxygen saturation (\%) during (a) autumn 1988 and (b) summer 1989 at all study sites. (The location of the tide gate relative to the study sites is indicated; the status of tide gate operation is shown for the dates sampled; hollow symbols: surface values; solid symbols: from the bottom)

was minimal outside the sediment basin (ST1 and ST2); however, within the basin conductivity was markedly higher at the bottom. Stratification appeared to increase in August at the stations for which there was sufficient data for comparison, with the exception of the shallowest station, ST1. The average surface/bottom difference in salinity (converted from conductivity) was $9.5 \%$ greater in August than in July at the 3 sediment basin stations (data not available for ST5). Surface conductivity was generally higher at downstream stations than at those further upstream (e.g. 8720 to $21200 \mu \mathrm{S} \mathrm{cm}^{-1}$ at ST6 vs 5400 to $17200 \mu \mathrm{S} \mathrm{cm}^{-1}$ at ST2 during July).

During the summer trials, daily mean values of dissolved oxygen at ST1 were not appreciably different between surface and bottom waters (Fig. 11). Although surface values at that station declined slightly over the course of the trials $\left(3.5\right.$ to $4.7 \mathrm{mg} \mathrm{I}^{-1}$ in July vs 2.5 to $3.6 \mathrm{mg} \mathrm{I}^{-1}$ in August), bottom values were generally equivalent during July and August (2.7 to $4.6 \mathrm{mg} \mathrm{l}^{-1}$ vs 2.5 to $3.9 \mathrm{mg} \mathrm{l}^{-1}$ ). The other stations had markedly lower DO at the bottom than at the surface during the summer trials (Fig. 11). Dissolved oxygen values were generally $>1 \mathrm{mg} \mathrm{l}^{-1}$ lower at the bottom, with greatest differences recorded among the sediment basin stations. Among stations for which there was sufficient data for comparison, all except ST1 had lower daily mean DO values (as much as 1.4 to $2.2 \mathrm{mg} \mathrm{l}^{-1}$ lower) during the August trials, compared to those recorded during the July trials. Daily average bottom DO values remained below $3.0 \mathrm{mg} \mathrm{l}^{-1}$ for most of the $10 \mathrm{~d}$ August 
Fig. 8. Differences between surface and bottom oxygen saturation $\left(\%\right.$ sat $_{\text {bott }}-\%$ sat $\left._{\text {surt }}\right)$ outside (BG1) and within (BG2) the sediment basin during periods of tide gate operation and nonoperation in autumn 1988

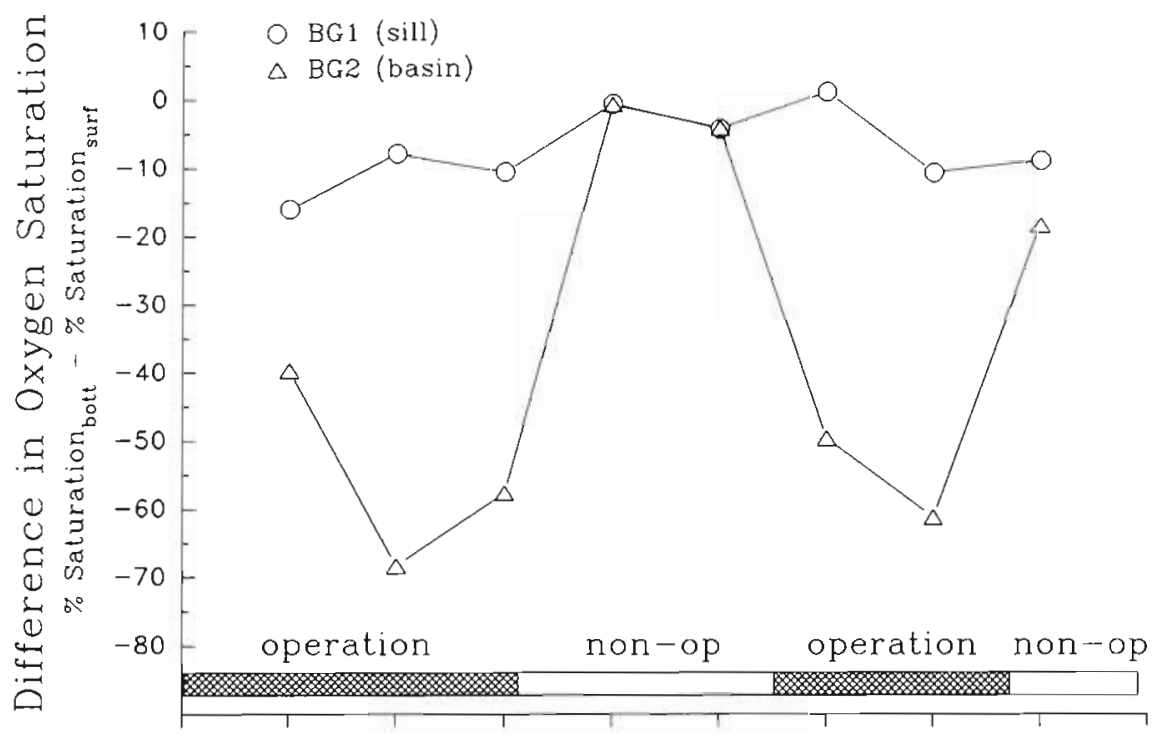

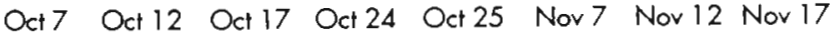

Sample date trial at all stations below the tide gate, with the lowest values recorded within the sediment basin.

\section{Laboratory tests}

\section{Salinity tolerance}

Tests on Gammarus tigrinus indicated that optimal survival occurred in salinities between 10 and $20 \%$ (Table 4), although slightly lower salinities resulted in only a small decrease in survival $(90 \%$ at $5 \%$ ). Signifi-

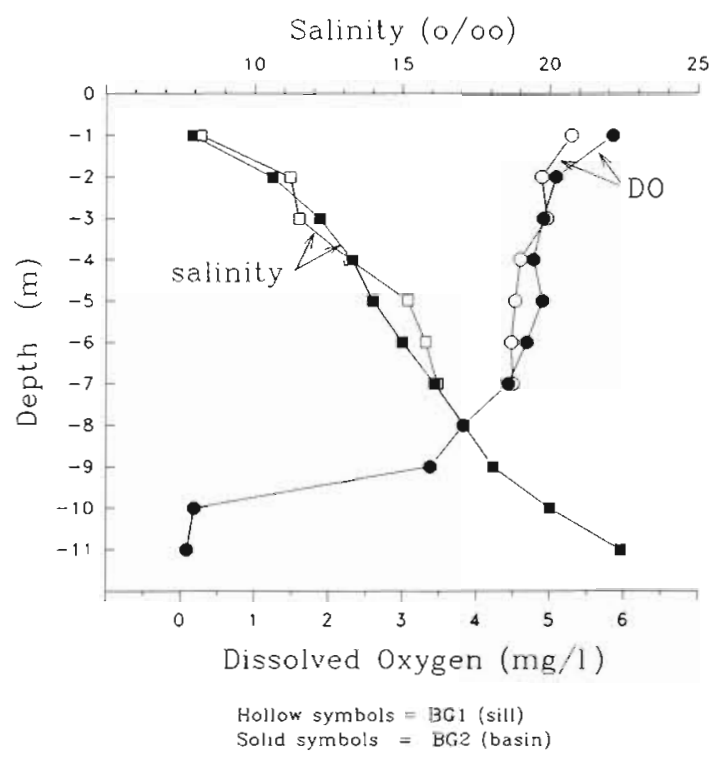

Fig. 9. Vertical profiles of salinity and dissolved oxygen outside ( $\mathrm{BG} 1$ ) and within (BG2) the sediment basin in autumn 1988 cant mortality was noted, however, at salinities outside that range (ANOVA; $F=71.6, \mathrm{df}=6, \mathrm{p}<0.001$ ). Greatest mortality occurred among amphipods exposed for $5 \mathrm{~d}$ to $30 \%$, where only $20 \%$ of the individuals survived. The onset of mortality was most immediate in freshwater $(0 \%$ ), where it was considerable following the first $24 \mathrm{~h}$ of exposure.

Mercenaria mercenaria exposed to salinities of $15 \%$ and greater for $10 \mathrm{~d}$ experienced no mortality (Table 4). At $10 \%$, however, some clams died after the 5 th day of exposure, and survival decreased significantly at salinities below that (ANOVA; $F=41.9$, df $=6$, $\mathrm{p}<0.001$ ). The onset of mortality among clams was more gradual than for amphipods, with survival remaining at $90 \%$ after $5 \mathrm{~d}$ even at the most unfavorable salinity $(0 \%)$.

\section{Dissolved oxygen tolerance of Gammarus tigrinus}

Gammarus tigrinus exhibited significant reductions in survival (ANOVA; $F=191.3$, df $=5, p<0.001$ ) after exposure for $6 \mathrm{~h}$ to the lower dissolved oxygen levels of 6 and $12 \%$ of saturation $(6 \%$ and $50 \%$ survival, respectively; Table 5). Initial mortality was observed at those levels after $3 \mathrm{~h}$ of exposure. No mortality occurred at higher DO test concentrations or in the nearly saturated controls.

\section{DISCUSSION}

\section{Field studies}

During the pilot study, the total mortality of amphipods placed near the bottom within the sedi- 


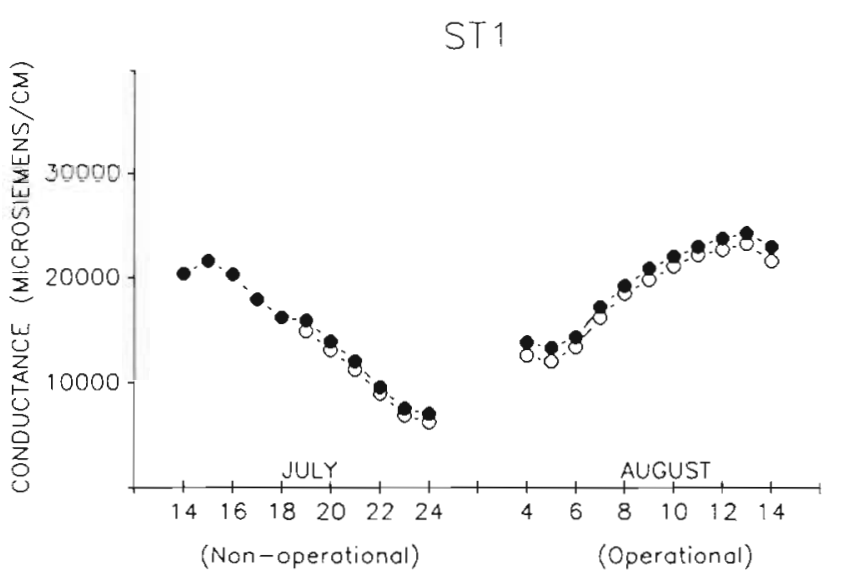

ST2

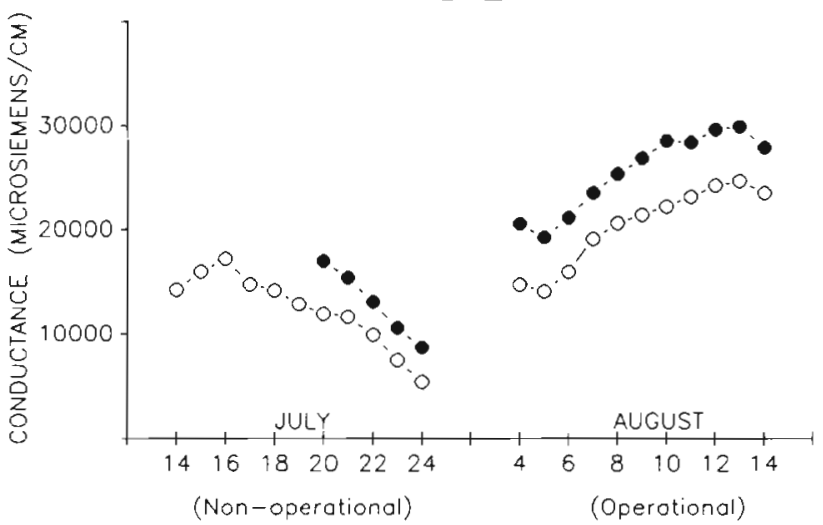

ST3

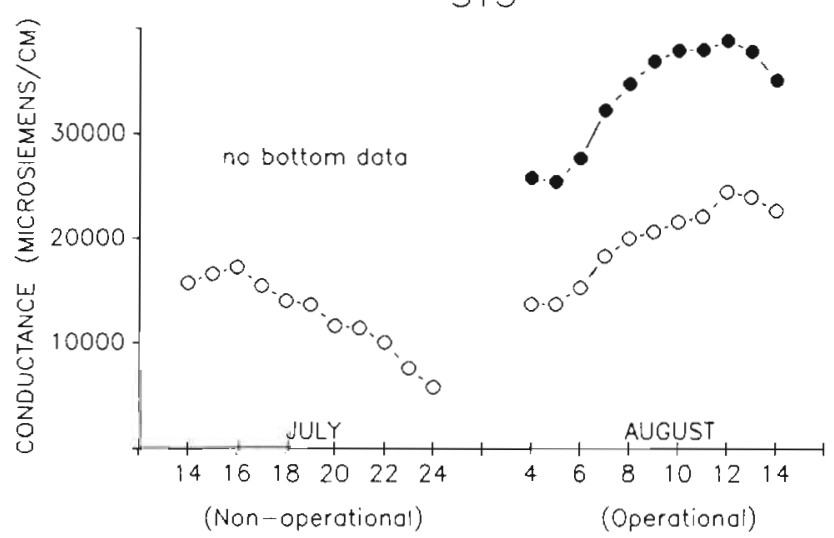

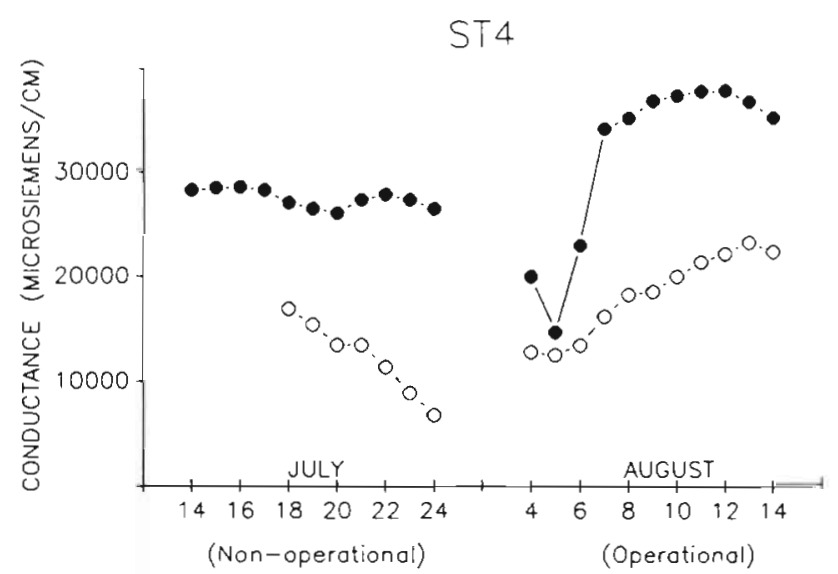

ST5

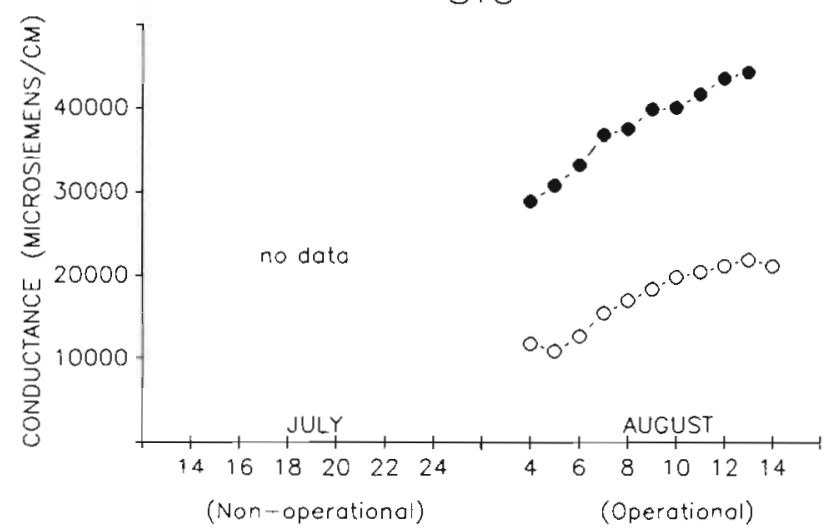

ST6

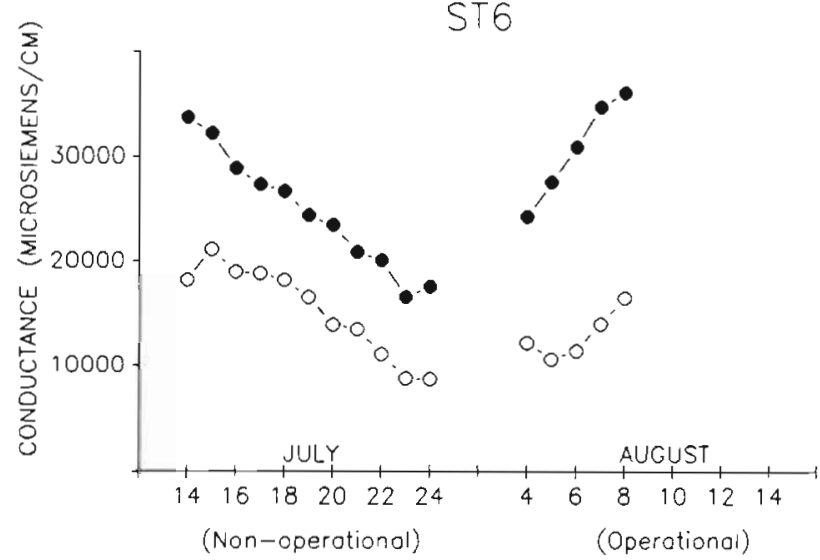

Fig. 10. Surface and bottom conductivity (daily means of hourly readings; $\mu \mathrm{S} \mathrm{cm}^{-1}$ ) during the summer (1989) trials. (0) Surface; $(\bullet)$ bottom

ment basin coincided with relatively high salinities $(22$ to $24 \%$ ) and extremely low levels of dissolved oxygen (1.2 to $22.4 \%$ of saturation) at that site. Although subsequent laboratory tests on the salinity tolerance of Gammarus tigrinus suggested that some mortality could be expected at salinities between 20 and $25 \%$, these levels of salinity probably contributed only slightly to the observed mortality. It is more likely that low DO levels accounted for most of the mortality, since DO tolerance tests showed that at levels between 12 and $18 \%$ of saturation the onset of mortal- ity occurred within $3 \mathrm{~h}$ of exposure. Sensitivity of amphipods to low DO has also been described for natural populations in a number of field studies. Harper et al. (1981), for example, concluded that amphipods were affected more severely than other macrofaunal taxa by extended hypoxia $\left(\leq 2 \mathrm{mg} \mathrm{l}^{-1}\right.$ for about 2 mo).

During the autumn trials, Gammarus tigrinus survival was significantly lower when the tide gate was operating than when it was non-operational. Comparisons of survival rates with measurements of dissolved 
oxygen during those trials, however, are rather equivocal. At stations outside the sediment basin, even though survival was consistently lower during tide gate operation, the levels of DO were generally higher at that time than during non-operation. This reflects a seasonal rise in ambient DO levels at those sites (from $43-62 \%$ of saturation during early October to $68-82 \%$ 1 mo later) which accompanied declining water temperatures. At the bottom of the sediment basin, even though a significant decline in dissolved oxygen coincided with operation of the tide gate, the lowest recorded values ( $16.3 \%$ of saturation) did not approach

ST 1
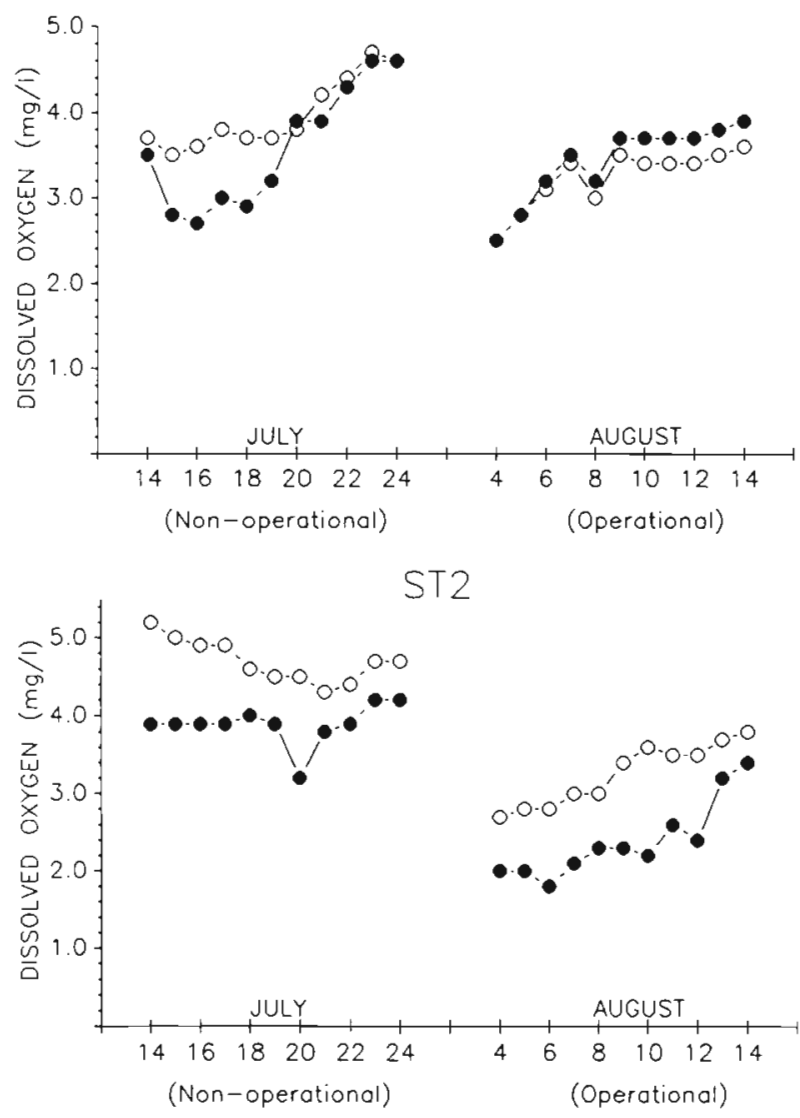

ST3

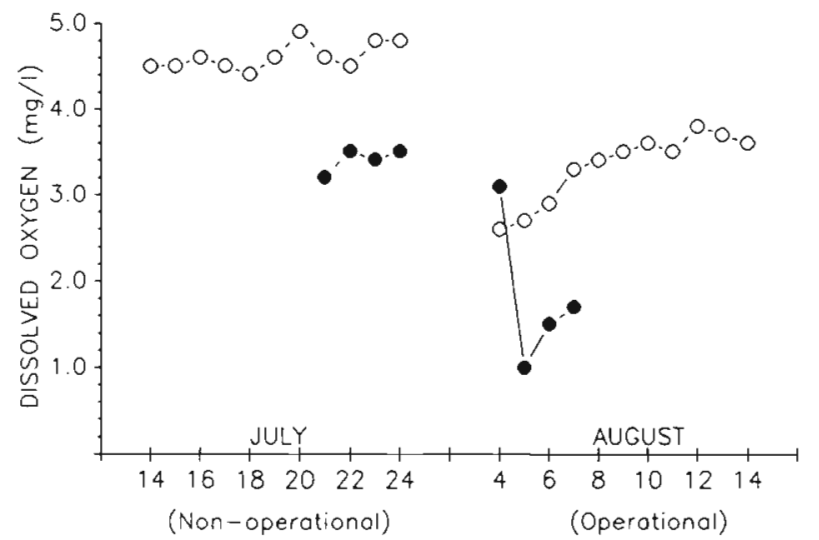

the minimum value observed during the earlier preliminary trials $(1.2 \%)$.

By the time of the summer trials, however, the relation between Gammarus tigrinus survival and dissolved oxygen became apparent once again. During non-operation of the tide gate, greatest mortality occurred at ST3 and ST4, where the lowest bottom DO values were observed (Figs. 4 \& 7b). The following month, during tide gate operation, bottom DO dropped precipitously at all stations within the sediment basin, particularly by the time of the second trial, and survival at all of those stations declined significantly.
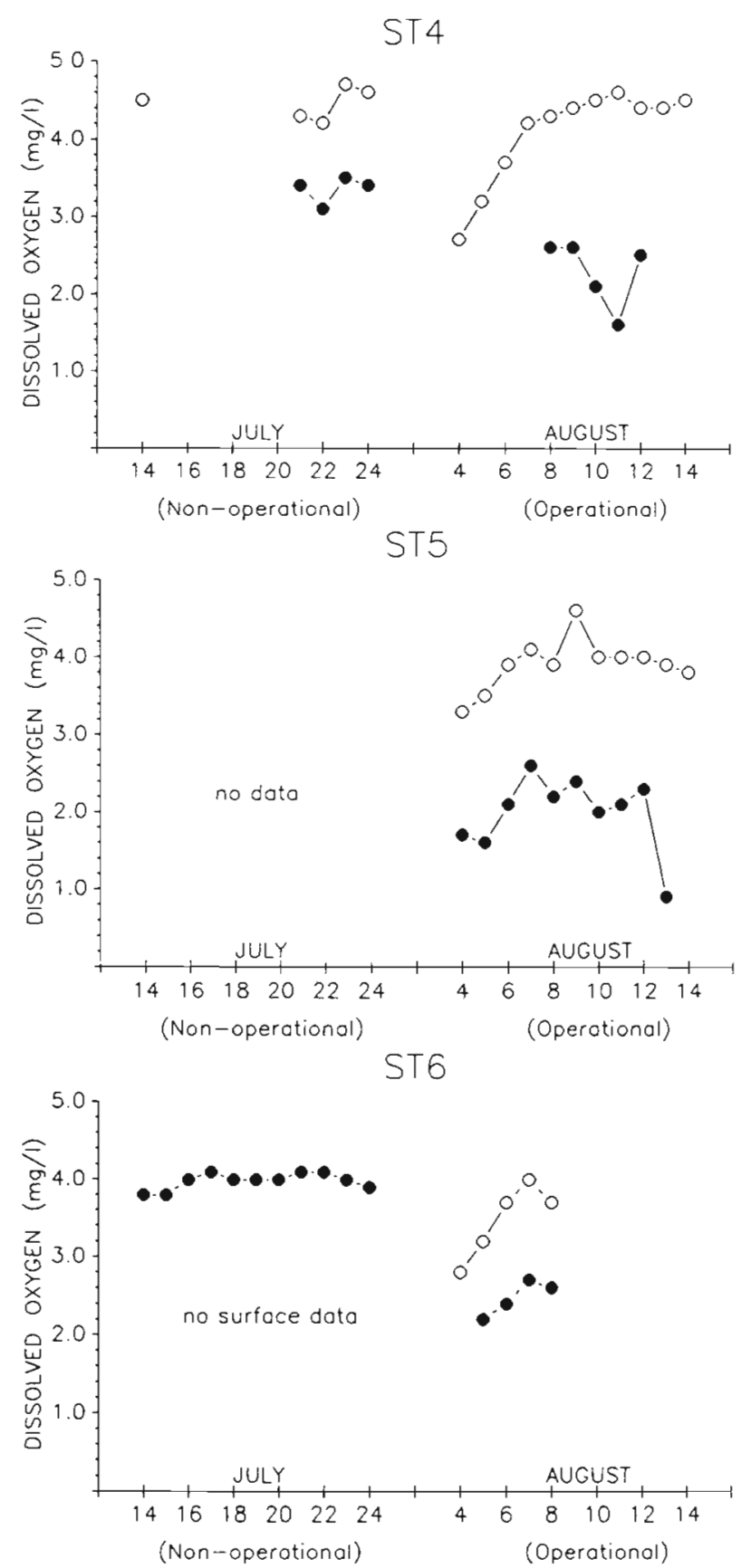

Fig. 11. Surface and bottom dissolved oxygen (daily means of hourly readings; $\mathrm{mg} \mathrm{l}^{-1}$ ) during the summer (1989) trials. (o) Surface; ( $\bullet$ bottom 
Table 4. Gammarus tigrinus and Mercenaria mercenaria. Survival (mean \%) in laboratory tests at various salinities. (Treatments connected by underlines are not significantly different from one another following a posteriori tests at $\alpha=0.05$ )

\begin{tabular}{|c|c|c|c|c|c|c|c|}
\hline \multirow{2}{*}{$\begin{array}{l}\text { Duration of } \\
\text { exposure (d) }\end{array}$} & \multicolumn{7}{|c|}{ Salinity $(\%)$} \\
\hline & 0 & 5 & 10 & 15 & 20 & 25 & 30 \\
\hline \multicolumn{8}{|c|}{ Gammarus tigrinus } \\
\hline 1 & 100 & 100 & 100 & 100 & 100 & 100 & 100 \\
\hline 2 & 65 & 100 & 100 & 100 & 100 & 90 & 90 \\
\hline 3 & 40 & 90 & 100 & 100 & 100 & 80 & 55 \\
\hline 4 & 40 & 90 & 100 & 100 & 100 & 75 & 30 \\
\hline 5 & 40 & 90 & 100 & 100 & 100 & 60 & 20 \\
\hline \multicolumn{8}{|c|}{ Mercenaria mercenaria } \\
\hline 1 & 100 & 100 & 100 & 100 & 100 & 100 & 100 \\
\hline 2 & 100 & 100 & 100 & 100 & 100 & 100 & 100 \\
\hline 3 & 100 & 100 & 100 & 100 & 100 & 100 & 100 \\
\hline 4 & 90 & 90 & 100 & 100 & 100 & 100 & 100 \\
\hline 5 & 90 & 90 & 100 & 100 & 100 & 100 & 100 \\
\hline 6 & 85 & 90 & 90 & 100 & 100 & 100 & 100 \\
\hline 7 & 70 & 80 & 80 & 100 & 100 & 100 & 100 \\
\hline 8 & 50 & 70 & 80 & 100 & 100 & 100 & 100 \\
\hline 9 & 45 & 60 & 80 & 100 & 100 & 100 & 100 \\
\hline 10 & 40 & 50 & 80 & 100 & 100 & 100 & 100 \\
\hline
\end{tabular}

Table 5. Gammarus tigrinus. Survival (mean \%) in laboratory tests at various levels of oxygen saturation. (Treatments connected by underlines are not significantly different from one another following a posteriori tests at $\alpha=0.05$ )

\begin{tabular}{|c|c|c|c|c|c|c|}
\hline $\begin{array}{l}\text { Duration of } \\
\text { exposure (h) }\end{array}$ & $\begin{array}{l}\text { Pel } \\
6 \%\end{array}$ & $\begin{array}{l}\text { cent o } \\
12 \%\end{array}$ & $\begin{array}{l}\text { xygen } \\
18 \%\end{array}$ & $\begin{array}{l}\text { satura } \\
24 \%\end{array}$ & tion & $\begin{array}{r}\text { Control } \\
84-96 \%\end{array}$ \\
\hline 1 & 100 & 100 & 100 & 100 & 100 & 100 \\
\hline 2 & 100 & 100 & 100 & 100 & 100 & 100 \\
\hline 3 & 98 & 94 & 100 & 100 & 100 & 100 \\
\hline 4 & 62 & 86 & 100 & 100 & 100 & 100 \\
\hline 5 & 46 & 72 & 100 & 100 & 100 & 100 \\
\hline 6 & 6 & 50 & 100 & 100 & 100 & 100 \\
\hline
\end{tabular}

The responses of other test species were less conclusive than those of Gammarus tigrinus. The preliminary tests with Mulinia lateralis indicated that although survival was somewhat reduced following a $5 \mathrm{~d}$ exposure to low DO conditions, the response was less pronounced than for amphipods (Fig. 2). Nor was clam survival significantly diminished as a result of tide gate operation during the full set of in situ trials in the autumn (Fig. 3). These findings are in agreement with those of other workers (e.g. Theede at al. 1969, McErlean et al. 1972, Stickle et al. 1989), who showed that mollusks are generally more tolerant of hypoxia than crustaceans. Increased mortality resulting from 5 additional days of exposure, however, sug- gests that $M$. lateralis is susceptible to low DO, as previously reported in Tampa Bay (Santos \& Simon 1980) and Chesapeake Bay (Holland et al, 1989). Although we were unable to obtain $M$. lateralis for our laboratory tests of DO tolerance, its survival in anoxic waters was determined by Shumway et al. (1983) to be $2 \mathrm{~d}$ or less $\left(\mathrm{LT}_{50}\right)$ for adults at ternperatures similar to ambient autumn temperatures in the Back River estuary. Those authors also noted that such a relatively short anoxic survival time places $M$. lateralis toward the lower end of the tolerance range among infaunal bivalves

Mercenaria mercenaria, which replaced Mulinia lateralis during the summer trials, is much more tolerant of low levels of dissolved oxygen. Savage (1976) previously demonstrated $100 \%$ survival of $M$. mercenaria for as long as 21 to $30 \mathrm{~d}$ at $0.9 \mathrm{mg} \mathrm{l}^{-1}$ and indicated that its burrowing ability was not severely or permanently impaired during those experiments.

Low surface salinities during the summer non-operational tests (2.9 to $6.9 \%$ ) were the likely cause of extreme mortality of Mercenaria mercenaria in surface cages at all stations during those tests, rather than low dissolved oxygen (Fig. 5). Percent oxygen saturation remained relatively high (40 to $69 \%$ ) during this period. Survival remained high through the first $5 \mathrm{~d}$ of the test, while the clams presumably avoided the unfavorable salinities by ceasing to pump and tightly closing their valves. The continuous decline of salinity during the second $5 \mathrm{~d}$ period (Fig. 10) apparently overwhelmed that resistance, resulting in extensive mortality. Similar mortality within natural populations of $M$. mercenaria has been attributed to low salinity by Haven et al. (1975), and a minimum salinity tolerance of 10 to $13 \%$ was suggested by Castagna \& Chanley (1973) for this species. Our salinity tolerance tests on $M$. mercenaria provided further evidence that salinities below about 10 $\%$ would be likely to result in mortality during a $10 \mathrm{~d}$ exposure period (Table 4). By the time of operational trials in August, surface salinities had risen considerably, ranging from 5.6 to $15.9 \%$. At the bottom, where salinities of 7.1 to $27.2 \%$ were recorded throughout the summer trials, survival remained greater than $93 \%$

\section{Oxygen depletion and its ecological consequences}

A comprehensive understanding of the spatial and temporal extent of hypoxia throughout the Savannah River estuary remains incomplete. However, the results of our monitoring of selected hydrographic parameters have shown that during the operation of the tide gate, a major reach of the estuary (at least 
$3 \mathrm{~km}$ ) regularly exhibits oxygen saturation levels below $30 \%$. These low levels can persist for several months during warm water temperatures, during which time the water column becomes extremely stratified. Surface and bottom oxygen saturation levels can differ by more than $50 \%$, with bottom DO levels approaching anoxia. The interruption of the normal ebb tidal flow caused by operation of the tide gate is clearly linked to the onset of increased stratification and the resultant DO depletion. The initial DO depletion, which is detectable within several days following reactivation of the tide gate, appears most pronounced immediately downstream of the tide gate and extends toward the lower estuary as conditions persist.

Although it is likely that oxygen depletion may be most extreme in the Back River estuary, and that operation of the tide gate contributes substantially to oxygen depletion, it is clear, nonetheless, that hypoxia does not always arise within, nor is confined to, the Back River estuary. Occurrences of hypoxia have been reported throughout the Savannah River estuary by various other researchers (Pennington \& Bond 1981, U.S. Army Corps of Engineers unpubl., J. Greenfield, U.S. Environmental Protection Agency, pers. comm.).

The effects of such oxygen depletion in other estuarine environments, particularly the mortality of benthic organisms resulting from recurring hypoxia, are being reported with increasing frequency (Boesch 1985). A number of recent investigations in the Gulf of Mexico (Pavela et al. 1983, Renaud 1986) and in Chesapeake Bay (Holland et al. 1989) have documented decreased abundance of certain commercially and ecologically important species.

Oxygen saturation levels below $30 \%$ were shown in this study to be lethal to experimental populations of amphipods and clams within hours to days of exposure in the estuary. The effects of oxygen depletion, however, were apparently not isolated to these experimental populations. The indigenous benthic infaunal communities sampled in the vicinity of the tide gate, where the hypoxia may persist for greater than 3 mo of the year, were severely impoverished with regard to total abundance and species richness, being comprised largely of species which characterize DOstressed environments elsewhere (Winn \& Knott 1990). The defaunation of the macrofauna and meiofauna communities suggests the benthos may be in a perpetual state of collapse and early recovery.

Estuarine organisms differ in their tolerances to chronic hypoxia and sensitivities to acute anoxia. Resistance to low oxygen levels appears to be correlated with an organism's natural habitats and metabolic activities, with the more active nektonic organisms showing less tolerance and greater sensitivity than benthic species (e.g. Theede et al. 1969, Theede 1973, Stickle et al. 1989). Various species of fishes, crustaceans and mollusks may behaviorally avoid hypoxic water masses, particularly if the waters are temporally and spatially isolated (e.g. Pavela et al. 1983, Renaud 1986). However, the occurrence of repeated and prolonged episodes of oxygen-depleted waters within the Savannah River estuary suggests that even the more motile organisms which have sensitive life history stages that move between the estuary and offshore waters (e.g. Callinectes sapidus, penaeid shrimp, shortnose sturgeon, striped bass) may be significantly affected. For such species which are unable to avoid hypoxic water masses, the effects may include substantial reductions in survival, as well as other sub-lethal effects (Stickle et al. 1989).

\section{Application of in situ studies to identification of hypoxia}

Standard bioassay techniques have often been used to describe the effects of specific contaminants on particular organisms. The present study represents an effort to adapt some of the concepts of laboratory bioassessment to field studies, as an alternative or adjunct to traditional community-level assessments such as the evaluation of abundance and diversity of the biota of the affected area. Although chemical and other water quality analyses are frequently used to characterize the nature of contamination in the aquatic environment, they often fail to provide useful information regarding the potential impact of such contamination on the natural resources of that environment. The value of the in situ trials in this study was that they demonstrated statistically significant reductions in survival of estuarine organisms during reduced DO conditions associated with tide gate operation. The mortality of the experimental populations transferred to sites on the river, the corroboration of these results by laboratory tolerance tests, and the interpretation of altered hydrography provided insight into the influence of the combined stress of changes in salinity, dissolved oxygen and other factors on estuarine organisms.

Acknowledgements. We wish to acknowledge the assistance of Glenn Patterson, Ted Kuny and the field crew of the U.S. Geological Survey for providing the water quality minimonitors. The efforts of Elizabeth Kennedy, who participated in field and laboratory phases of the study, as well as data analysis and report preparation, are greatly appreciated. Robert Steffen and Mary Levisen also provided assistance in the laboratory and field, and Mary Jo Clise assisted with the computer analyses. Our appreciation is also extended to $J$. R. 
Peavy and R. W. Gladden of the U.S. Army Corps of Engineers, Savannah District, whose efforts were instrumental in the initiation and funding of this part of the Savannah Harbor Environmental Study.

\section{LITERATURE CITED}

APHA (American Public Health Association) (1980). Standard methods for the examination of water and wastewater, 15th edn. American Public Health Association, New York

Bennett, C. S., Cooney, T W., Jones, K. H., Church, B. W., Murray, G. L. (1990). Water resources data: South Carolina - water year 1989. Report No. USGS/WRD/HD90/263 of the US Geological Service, Water Resources Division, Columbia, South Carolina, p. 466-507

Benson, B. B., Krause, D. Jr (1984). The concentration and isotopic fractionation of oxygen dissolved in freshwater and seawater in equilibrium with the atmosphere. Limnol. Oceanogr. 29: 620-632

Boesch, D. F. (1985). Effects on benthos of oxygen depletion in estuarine and coastal waters. In: The occurrence of hypoxic and anoxic conditions in estuaries and coastal environments. Eighth Biennial International Estuarine Research Conference. Abstracts in Estuaries 8 (2B): 43A

Boesch, D. F., Wass, M. L., Virnstein, R. W. (1976). In: Wiley, M. L. (ed.) Estuarine processes, Vol. I, Uses, stresses, and adaptation to the estuary. Academic Press, New York, p. 177-196

Castagna, M., Chanley, P. (1973). Salinity tolerance of some marine bivalves from inshore and estuarine environments in Virginia waters on the western mid-Atlantic coast. Malacologia 12: 47-96

Eversole, A. G. (1987). Species profiles: life histories and environmental requirements of coastal fishes and invertebrates (South Atlantic) - hard clam. U.S. Fish Wildl. Serv. Biol. Rep. 82 (11.75). U.S. Army Corps of Engineers, TR EL$82-4$

Harper, D. E. Jr, McKinney, L. D., Salzer, R. R., Case, R. J. (1981). The occurrence of hypoxic bottom water off the upper Texas coast and its effects on the benthic biota. Contr. mar. Sci. 24: 53-79

Haven, D. S., Hargis, W. J., Loesch, J. G., Whitcomb, J. P. (1975). The effect of tropical storm Agnes on oysters, hard clams, soft clams and oyster drills. Chesapeake Research Consortium Publication No. 34: D170-D208, Solomons, $\mathrm{MD}$

Holland, A. F., Shaughnessy, A. T., Scott, L. C., Dickens, V A.. Gerritsen, J., Ranasinghe, J. A. (1989). Long-term benthic monitoring and assessment program for the Maryland portion of Chesapeake Bay: Interpretive Report. Power Plant Research Program, CBRM-LTB/EST89-2, Annapolis, MD

Mathews, T. D., Stapor, F. W Jr, Richter, C. R., Miglarese, J. V., McKenzie, M. D., Barclay, L. A. (1980). Ecological characterization of the Sea Island coastal region of South Carolina and Georgia. Vol. I. Physical features of the characterization area. US Fish and Wildlife Service, FWS' OBS-79/40

McErlean, A. J., Kerby, C., Swartz, R. C., Kohlenstein, L. C. (1972). Conclusions and recommendations. Chesa- peake Sci. 13 (Suppl: Biota of the Chesapeake Bay): S8-S16

Officer, C. B., Biggs, R. B., Taft, J. L., Cronin, L. E., Tyler, M. A., Boynton, W. R. (1984). Chesapeake Bay anoxia: origin, development, and significance. Science 223: 22-27

Pavela, J. S., Ross, J. L., Chittenden, M. E. Jr (1983). Sharp reductions in abundance of fishes and benthic macroinvertebrates in the Gulf of Mexico off Texas associated with hypoxia. Northeast Gulf Sci. 6: 167-173

Pearlstine, L. G., Bartleson, R. D., Kitchens, W. M., Latham. P. J. (1989). Lower Savannah River hydrological characterization. Technical Report No. 35, Cooperative Fish and Wildlife Research Unit, University of Florida, Gainesville

Pennington, C. H., Bond, C. L. (1981). Savannah River estuary study. Vol. I: Water quality report. Draft report. U.S. Army Engineer Waterways Experiment Station, Vicksburg, MS

Renaud, M. L. (1985). Annotated bibliography on hypoxia and its effects on marine life, with emphasis on the Gulf of Mexico. NOAA Technical Report NMFS 21

Renaud, M. L. (1986). Hypoxia in Louisiana coastal waters during 1983: implications for fisheries. Fish. Bull. U.S. 84: $19-26$

Santos, S. L., Simon, J. L. (1980). Response of soft-bottom benthos to annual catastrophic disturbance in a South Florida estuary. Mar. Ecol. Prog. Ser. 3: 347-355

Savage, N. B. (1976). Burrowing activity in Mercenaria mercenaria (L.) and Spisula solidissima (Dillwyn) as a function of temperature and dissolved oxygen. Mar behav. Physiol 3: 221-234

Schroeder, W. W (1985). The occurrence of hypoxic and anoxic conditions in estuaries and coastal environments Eighth Biennial International Estuarine Research Conference. Abstracts in Estuaries 8(2B): 43A-47 A

Shumway, S. E., Scott, T. M., Shick, J. M. (1983). The effects of anoxia and hydrogen sulphide on survival, activity and metabolic rate in the coot clam, Mulinia lateralis (Say). J. exp. mar. Biol. Ecol. 71. 135-146

Siegler, H. H., Boggs, J. A., Biggley, W H. (1985). Catastrophic anoxia in the Chesapeake Bay in 1984. Science 228: $70-73$

Sokal, R. R., Rohlf, F. J. (1981). Biometry. The principles and practice of statistics in biological research, 2nd edn. W. H. Freeman and Company, New York

Stickle, W. B., Kapper, M. A., Liu, L., Gnaiger, E., Wang, S. Y (1989). Metabolic adaptations of several species of crustaceans and mollusks to hypoxia: tolerance and microcalorimetric studies. Biol. Bull. 177: 303-312

Theede, H., Ponat, A., Kiroki, K., Schlieper, C. (1969). Studies on the resistance of marine bottom invertebrates to oxygen deficiency and hydrogen sulfide. Mar. Biol. 2: 325-337

Theede, H. (1973). Comparative studies on the influence of oxygen deficiency and hydrogen sulfide on marine bottom invertebrates. Neth. J. Sea. Res. 7: 244-252

Walker, R. L., Tenore, K. R. (1984). Growth and production of the dwarf surf clam Mulinia lateralis (Say 1822) in a Georgia estuary. Gulf Res. Rep. 7-357-363

Williams, J. B. (1984). Respiratory changes in the euryhaline clam, Mulinia lateralis (Say), over a broad range of temperature and salinity combinations. J exp. mar. Biol. Ecol. 81. 269-280 
Winn, R. N., Knott, D. M. (1990). Savannah Harbor Environmental Study: Task C - Experimental Field Studies. Report to the U.S. Army Corps of Engineers, Savannah

This article was submitted to the editor
District, by Marine Resources Research Institute, South Carolina Wildlife and Marine Resources Department, Charleston

Manuscript first received: July 21, 1992

Revised version accepted: October 2, 1992 